\title{
Mali: Technical Assistance Report-Public Investment Management Assessment
}




\section{INTERNATIONAL MONETARY FUND}

IMF Country Report No. 18/114

\section{MALI}

\section{TECHNICAL ASSISTANCE REPORT—PUBLIC INVESTMENT MANAGEMENT ASSESSMENT}

This Technical Assistance report on Mali was prepared by a staff team of the International Monetary Fund. It is based on the information available at the time it was completed in August 2017.

Copies of this report are available to the public from

International Monetary Fund $\bullet$ Publication Services

PO Box $92780 \bullet$ Washington, D.C. 20090

Telephone: (202) 623-7430 • Fax: (202) 623-7201

E-mail: publications@imf.org Web: http://www.imf.org

Price: $\$ 18.00$ per printed copy

\section{International Monetary Fund \\ Washington, D.C.}

(C) 2018 International Monetary Fund

CInternational Monetary Fund. Not for Redistribution 


\section{FISCAL AFFAIRS DEPARTMENT}

\section{Mali \\ Public Investment Management Assessment (PIMA)}

Benoît Taiclet, Gwénaëlle Suc, Nicolas Botton, Fabienne Mroczka, Onintsoa Raoilisoa, Pierre Roumegas, and Yemdaogo Tougma

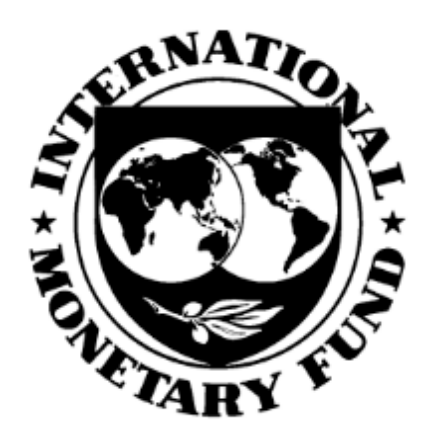

Technical Assistance Report

August 2017 


\section{TABLE OF CONTENTS}

ACRONYMS AND ABBREVIATIONS

PREFACE

EXECUTIVE SUMMARY

I. PUBLIC INVESTMENT IN MALI: CONTEXT

A. Patterns of Public Investment and Fixed Capital Stock

B. Quality, Efficiency, and Impact of Public Investment 14

II. PUBLIC INVESTMENT MANAGEMENT ASSESSMENT

A. Pillar I: Planning

B. Pillar II: Allocating $\underline{29}$

C. Pillar III. Implementing $\frac{37}{43}$

D. Cross-Cutting Issues and Capacities

\section{BOXES}

1. Public Investment Management Assessment Framework (PIMA) 20

2. Definition of Payment Arrears on Capital Expenditure $\frac{39}{41}$

3. Players Involved in Execution Processes

$\underline{41}$

\section{FIGURES}

1. Mali and Comparable Countries: Institutional Framework for Public Investment Management_ $\underline{8}$

2. Institutional Framework and its Effectiveness

3. Total, Public, and Private Investment _____ _ _ _ _ _ _ _ _ _ _ _ _ _

4. Public Investment and GDP Growth ___

5. Financing Sources for Capital Expenditure (billions of CFAF)____ _ _ _

6. Share of Capital Expenditure in the Budget (percentage of GDP) ___

7. Stock of Public Capital and Public Debt____

8. Stock of Public Capital Stock Per Capita (2015) ___

9. Indicators of Access to Public Infrastructures ___ _ _

10. Perception of the Quality of Infrastructures ___

11. Efficiency Threshold (hybrid indicator) ___

12. Efficiency Indicator (PIE-X) ____ _ _ $\frac{17}{17}$

13. Efficiency Indicator (PIE-X), Quality Component_____

14. Efficiency Indicator (PIE-X), Physical Component ___ _ _

15. Comparative Developments in Public Debt and Capital Expenditure ___ _

16. Composition of Investment Resources in Local Governments ___ _ _ _ _ _ _ _ _ _

17. Share of Operating and Capital Expenditure in Local Budgets____ 26

18. Stock of Capital in Connection with PPPs in Mali as Compared with Other Countries of Francophone Africa 
19. Distribution of Capital Expenditure, 2015-2017

20. Composition of the Special Capital Budget with Domestic Financing, 2017

21. Information Systems Involved in Public Investment Management Are Not Integrated

22. Procurement Trends

23. Trends in Maintenance Costs Under the State Budget

\section{TABLES}

1. Summary of the Assessment

2. Summary Assessment, Pillar I

3. Trends in WAEMU Convergence Indicators for Mali

4. Examples of Sectoral Strategic Indicators

5. Summary Assessment, Pillar II $\underline{30}$

6. Distribution of Capital Expenditure 2015-2017 $\underline{32}$

7. Summary Assessment, Pillar III

8. Summary Assessment of Cross-Cutting Issues and Capacities $\frac{44}{49}$

9. Public Procurement Contracting Periods

\section{ANNEX}

I. PIMA Questionnaire 


\section{ACRONYMS AND ABBREVIATIONS}

\begin{tabular}{|c|c|}
\hline AICE & Integrated government computerized accounting application \\
\hline ANICT & National investment agency for local governments \\
\hline ARMDS & Regulatory authority for public procurement \\
\hline BCEAO & Central Bank of West African States \\
\hline BSI & Special investment budget \\
\hline BVG & Office of the Auditor General \\
\hline CA & Commitment authorization \\
\hline CCOCSAD & $\begin{array}{l}\text { Municipal committees for steering, coordination, and monitoring of } \\
\text { development activities }\end{array}$ \\
\hline CFAF & African financial community franc \\
\hline CLOCSAD & $\begin{array}{l}\text { Local committees for steering, coordination, and monitoring of } \\
\text { development activities }\end{array}$ \\
\hline CNO & National Steering committee \\
\hline CNPE & National Economic Policy Committee \\
\hline $\mathrm{CP}$ & Payment allocations \\
\hline CPS & Strategic planning unit \\
\hline CREDD & Framework for economic recovery and sustainable development \\
\hline CROCSAD & $\begin{array}{l}\text { Regional committees for steering, coordination, and monitoring of } \\
\text { development activities }\end{array}$ \\
\hline CUT & Treasury single account \\
\hline DAO & Bidding documents \\
\hline DFM & Finance and Materials Directorate \\
\hline DGABE & Directorate General of Government Asset Management \\
\hline DGB & Directorate General of Budget \\
\hline DGD & Directorate General of Customs \\
\hline DGDP & Directorate General of Public Debt \\
\hline DGI & Directorate General of Taxes \\
\hline DGMP-DSP & Directorate General of Public Procurement and Public Service Delegation \\
\hline DNCF & National Financial Supervision Directorate \\
\hline DNPD & National Development Planning Directorate \\
\hline DNTCP & National Treasury and Public Accounting Directorate \\
\hline DPEBP & Multiyear Budget and Economic Programming Document \\
\hline ECOWAS & Economic Community of West African States \\
\hline EDM & Énergie du Mali (Mali's utility) \\
\hline EPIC & Public industrial and commercial institution \\
\hline FAD & Fiscal Affairs Department, IMF \\
\hline FNACT & National fund to support local governments \\
\hline GDP & Gross domestic product \\
\hline GFCF & Gross fixed capital formation \\
\hline IF & Finance Inspection \\
\hline INSTAT & National Statistics Office \\
\hline JICA & Japan International Cooperation Agency \\
\hline LLF & Law on Budget Laws \\
\hline MDOD & Contract authority's representative \\
\hline
\end{tabular}




$\begin{array}{ll}\text { Mds } & \text { Billions } \\ \text { MEF } & \text { Ministry of Economy and Finance } \\ \text { MTEF } & \text { Medium-term expenditure framework } \\ \text { MTERF } & \text { Medium-term external resource framework } \\ \text { PCE } & \text { Government chart of accounts } \\ \text { PDESC } & \text { Economic, social, and cultural development program } \\ \text { PE } & \text { Commitment plan } \\ \text { PEC } & \text { Consolidated commitment plan } \\ \text { PEFA } & \text { Public Expenditure and Financial Accountability Program } \\ \text { PES } & \text { Sectoral commitment plan } \\ \text { PIE-X } & \text { Public investment efficiency index } \\ \text { PIMA } & \text { Public investment management assessment } \\ \text { PPM } & \text { Public procurement contracting plan } \\ \text { PPMC } & \text { Consolidated public procurement contracting plan } \\ \text { PPMS } & \text { Sectoral public procurement contracting plan } \\ \text { PPP } & \text { Public-private partnership } \\ \text { PRED } & \text { Program of economic reform for development (software to monitor } \\ & \text { budget execution) } \\ \text { PT } & \text { Cash flow plan } \\ \text { PTI } & \text { Three-year investment plan } \\ \text { RGCP } & \text { General regulation on public accounting } \\ \text { SDG } & \text { Sustainable development goals } \\ \text { SDI } & \text { Information technology master plan } \\ \text { SHA } & \text { Secretariat for Aid Harmonization } \\ \text { SIGIP } & \text { Integrated public investment management system } \\ \text { TFP } & \text { Technical and financial partners } \\ \text { WB } & \text { World Bank }\end{array}$




\section{PREFACE}

At the request of Dr. Boubou Cissé, Minister of Finance and Economy of Mali, a mission from the Fiscal Affairs Department (FAD) of the International Monetary Fund (IMF) and the World Bank visited Bamako during June 1-15, 2017 to work on the public investment management assessment using the Public Investment Management Assessment (PIMA) methodology.

The mission, led by Benoit Taiclet (Senior Economist, FAD), included Gwénaëlle Suc (Economist, FAD), Fabienne Mroczka and Yemdaogo Tougma (Economists, World Bank), Nicolas Botton (Resident Adviser for Mali, FAD), and Onintsoa Raoilisoa and Pierre Roumegas (Experts, FAD).

On June 16, at the end of the visit, the mission held a wrap up meeting, and presented Dr. Boubou Cissé with the mission's preliminary conclusions during. A draft version of the report was given to staff of the Ministry of Economy and Finance (MEF) during this meeting.

The mission worked closely with Bamoussa Koné (National Director of Planning and Development), Sidiki Traoré (Director General of Budget), Sidi Almoctar (National Director of Treasury and Public Accounting), Boubacar Ben Bouillé (Director General of Public Procurement), and their respective staff members.

The mission held working meetings with the Accounting Section of the Supreme Court; the Public Private Partnership (PPP) Unit of the Office of the Prime Minister; the Office of the Auditor General; staff from the Central Bank of West African States (BCEAO); staff from the Inspectorate General of Finance; the Directorate General of Government Asset Management (DGABE); the Directorate General of Public Debt (DGDP); the National Financial Supervision Directorate (DNCF); the National Statistics Office (INSTAT); the National Investment Agency for Local governments (ANICT); senior management from Énergie du Mali (EDM); strategic planning units, and finance and materials directorates from the ministries responsible for national education, mining, energy and water, health and public hygiene, decentralization and government reform, equipment, and improved access.

The mission also met with Mali's technical and financial partners, Arsène Kaho from the World Bank; Dicko Hamaciré from African Development Bank; Myriam Bacquelaine, Head of the Diplomatic Mission of the Embassy of Belgium; Bernard Dagouassat and Jacques Batut of the Embassy of France; Jan Meise from the Embassy of Germany; Lieve Deherder from the Embassy of Denmark; and Michiko Miyamoto and Mamadou Barry of the Japan International Cooperation Agency (JICA).

The mission would like to thank the Mali authorities for their warm welcome, availability, and generous hospitality during this mission.

The mission extends its appreciation to Abdoulaye Tall, Resident Representative, IMF, and his staff for facilitating its work and for their valuable support. 


\section{EXECUTIVE SUMMARY}

1. This Public Investment Management Assessment (PIMA) for Mali brings to light a robust, although paradoxically inefficient, management framework. In accordance with the methodology prepared by the Fiscal Affairs Department (FAD), IMF, this PIMA takes stock of public investment, its features, and its efficiency, and subsequently reviews the management procedures to identify any present weaknesses (see Table 1). In Mali, the management framework is fairly robust when compared to other countries of the sub region and other developing countries, however it produces very little sustainable fixed capital per unit of capital expenditure per capita.

\section{The institutional strength of the public investment management framework is good} compared to peer countries. The assessment of the 15 institutions (or components) of the framework pictures generally good scores, at or above average levels for low-income countries (LICs) in almost all components (Figure 1). There are four exceptions: the institutional framework for public private partnerships (PPPs) is incomplete; there is scope for improvement in accounting and valuation of assets, and particularly non-financial assets; availability of financing for investments suffers from poor commitment management and cash flow projections; and last, project assessment is not systematic or comprehensive. These deviations from good practices are being corrected with the implementation of the new legal framework that complies with regional directives of the West African Economic and Monetary Union (WAEMU). Despite a few weaknesses in financial relations with local government, management of PPPs, regulation of investment supply, and selection of projects (institutions 3,4,5, and 10), this framework is relatively robust and effective (Figure 2).

\section{Compared with Mali's investment efforts the public investment management (PIM)} system does not produce a sufficient stock of sustainable fixed capital. Administrative culture of efficiency is not widespread and staff generally do not master the tools of financial or risk analysis. While managers seem concerned with the formal application of procedures, they are insufficiently focused on delivering practical, measurable, least-costs and timely outputs. Despite the efforts of the government and partners to generate budget resources, public gross fixed capital formation is extremely irregular and has been on a downward trend in the long term. The fixed capital stock grows at a slower pace than the economy and the population, positioning Mali among the least equipped countries in the sub region in terms of fixed capital per capita. This poor performance derives from a substantial efficiency gap: in Mali only 57 percent of capital expenditure materializes in fixed capital stock, compared with an average of 73 percent in the rest of the world.

\section{This report's recommendations aim to reduce the PIM efficiency gap. The paper} proposes to break with the above indicated paradox as (a fairly robust, albeit inefficient system), through optimizing the institutional framework without any fundamental changes to it. The overarching objective is to change the administrative practices to produce sustainable infrastructures, of higher-quality. The action plan below follows three approaches (Part III): 1. to optimize existing resources; 2 . to mobilize resources and devote them to investment; and 3 . to improve the sustainability of the stock of infrastructures. A cross-cutting approach (4) aiming to establish a results-based culture of integrity, by raising the professional standards of management, should support implementation of these three operational approaches. 
Figure 1. Mali and Comparable Countries: Institutional Framework for Public Investment Management

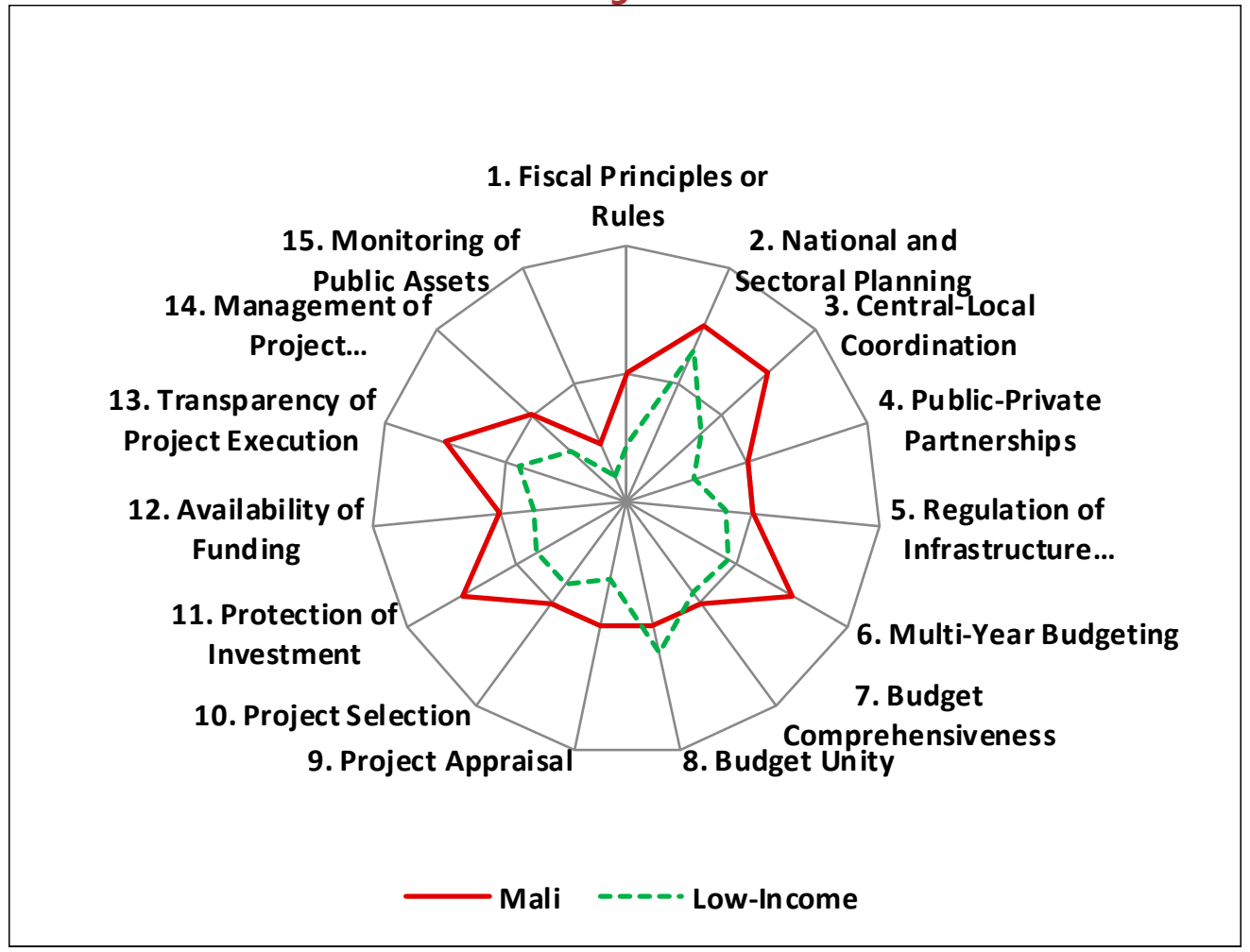

Figure 2. Institutional Framework and its Effectiveness

\section{Fiscal Principles or}

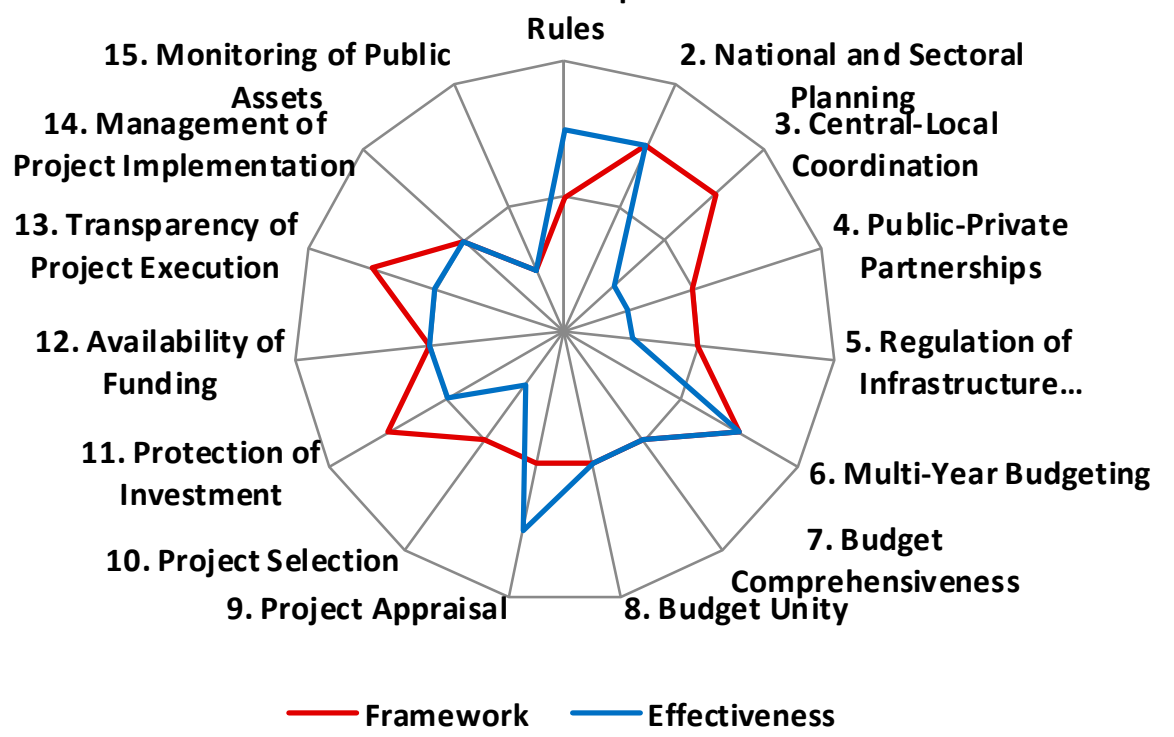


Table 1. Summary of the Assessment

\begin{tabular}{|c|c|c|c|c|}
\hline \multicolumn{2}{|c|}{ Étape/Institution } & \multirow{2}{*}{$\begin{array}{l}\text { Force } \\
\text { institutionnelle } \\
\text { Moderate. The permanent fiscal rules } \\
\text { no longer specifically apply to capital } \\
\text { expenditure. }\end{array}$} & \multirow{2}{*}{$\begin{array}{l}\text { Effectivité } \\
\text { High. The level of capital expenditure } \\
\text { is preserved while debt is limited to } \\
\text { the ceilings established by the } \\
\text { WAEMU. }\end{array}$} & \multirow{2}{*}{$\begin{array}{l}\text { Priorité } \\
\text { des } \\
\text { réformes } \\
\qquad *\end{array}$} \\
\hline 1 & Fiscal rules & & & \\
\hline 2 & $\begin{array}{l}\text { National and } \\
\text { sectoral } \\
\text { planning }\end{array}$ & $\begin{array}{l}\text { High. The three-year investment plan, } \\
\text { which is published, breaks the } \\
\text { national investment strategy down by } \\
\text { sector. Preparation of the three-year } \\
\text { investment plan is based on an } \\
\text { ascending partnership process. }\end{array}$ & $\begin{array}{l}\text { High. Sectoral and national strategies } \\
\text { are properly coordinated, reviewed } \\
\text { every year, and consolidated into a } \\
\text { unified document that presents the } \\
\text { key indicators for economic activity } \\
\text { and impact for each sector. }\end{array}$ & * \\
\hline 3 & $\begin{array}{l}\text { Coordination } \\
\text { between the } \\
\text { central } \\
\text { authorities and } \\
\text { local } \\
\text { governments }\end{array}$ & $\begin{array}{l}\text { High. Recourse to borrowing for } \\
\text { investment by local governments is } \\
\text { limited by law. The amount of } \\
\text { transfers is known more than six } \\
\text { months before the beginning of the } \\
\text { fiscal year. Planning is coordinated on } \\
\text { a concerted basis. }\end{array}$ & $\begin{array}{l}\text { Low. The financial and operational } \\
\text { role of local governments in the } \\
\text { financing efforts is practically very } \\
\text { low. }\end{array}$ & $* * *$ \\
\hline 4 & $\begin{array}{l}\text { Public-private } \\
\text { partnerships }\end{array}$ & $\begin{array}{l}\text { Moderate. The } 2016 \text { Law on PPPs is } \\
\text { in the process of implementation. It } \\
\text { does not provide a general definition } \\
\text { of PPPs and does not impose the } \\
\text { principle of a ceiling on multiyear } \\
\text { guarantees or commitments. } \\
\text { Monitoring of financial commitments } \\
\text { in connection with PPPs is not } \\
\text { organized. }\end{array}$ & $\begin{array}{l}\text { Low. PPPs undertaken prior to } 2016 \\
\text { have not been subject to preliminary } \\
\text { studies. Financial commitments are } \\
\text { not systematically recorded. }\end{array}$ & $* * *$ \\
\hline 5 & $\begin{array}{l}\text { Regulation of } \\
\text { infrastructure } \\
\text { enterprises }\end{array}$ & $\begin{array}{l}\text { Moderate. Major economic } \\
\text { infrastructure contracts undergo } \\
\text { international and national } \\
\text { competitive bidding procedures. } \\
\text { These contracts are regulated by } \\
\text { independent authorities, and prices } \\
\text { are unrestricted, except for electricity. } \\
\text { Surveillance of public infrastructure } \\
\text { enterprises in insufficient. }\end{array}$ & $\begin{array}{l}\text { Low. Because of insufficient } \\
\text { structured surveillance, investment } \\
\text { plans of public enterprises are not } \\
\text { reviewed by government staff. } \\
\text { Financial risks in connection with } \\
\text { enterprises' investment operations } \\
\text { are not monitored in a consolidated } \\
\text { report. }\end{array}$ & $* * *$ \\
\hline 6 & $\begin{array}{l}\text { Programmation } \\
\text { pluriannuelle }\end{array}$ & $\begin{array}{l}\text { High. Capital expenditure of the } \\
\text { ministries is subject to multiyear } \\
\text { programming and ceilings to reflect } \\
\text { all project costs, and is published. }\end{array}$ & $\begin{array}{l}\text { High. Although program budget } \\
\text { implementation will not be effective } \\
\text { until } 2018 \text {, the multiyear } \\
\text { programming system is consistent. }\end{array}$ & * \\
\hline 7 & $\begin{array}{l}\text { Caractère } \\
\text { exhaustif du } \\
\text { budget }\end{array}$ & $\begin{array}{l}\text { Moderate. While capital expenditure } \\
\text { is generally executed in line with the } \\
\text { budget, the Budget does not contain } \\
\text { any information on PPPs. }\end{array}$ & $\begin{array}{l}\text { Moderate. Recording of externally- } \\
\text { financed capital expenditure is not } \\
\text { complete. Transactions of PPPs are } \\
\text { not monitored. }\end{array}$ & * \\
\hline 8 & Unité du budget & $\begin{array}{l}\text { Moderate. The budget is prepared } \\
\text { with an economic, administrative, and } \\
\text { functional nomenclature. There is a } \\
\text { presentation by program appended } \\
\text { to the Budget Law. }\end{array}$ & $\begin{array}{l}\text { Moderate. Transition to the program } \\
\text { budget is planned for } 2018 \text {. } \\
\text { Investment-related recurring } \\
\text { expenditure is recorded in the } \\
\text { budget, but not disaggregated by } \\
\text { project. }\end{array}$ & $* *$ \\
\hline
\end{tabular}


Table 1. Summary of the Assessment

\begin{tabular}{|c|c|c|c|c|}
\hline \multicolumn{2}{|c|}{ Étape/Institution } & \multirow{2}{*}{$\begin{array}{l}\text { Force } \\
\text { institutionnelle } \\
\text { Moderate. The process for } \\
\text { investment project preparation } \\
\text { includes ex ante assessment. The } \\
\text { assessment methodology is under } \\
\text { review. }\end{array}$} & \multirow{2}{*}{$\begin{array}{l}\text { Effectivité } \\
\text { Low. Major structuring projects are } \\
\text { not systematically subject to a cost- } \\
\text { benefit analysis using a standard } \\
\text { methodology. The risk analysis is still } \\
\text { limited. }\end{array}$} & \multirow{2}{*}{$\begin{array}{l}\text { Priorité } \\
\text { des } \\
\text { réformes } \\
\qquad * * *\end{array}$} \\
\hline 9 & $\begin{array}{l}\text { Évaluation ex } \\
\text { ante des projets }\end{array}$ & & & \\
\hline 10 & $\begin{array}{l}\text { Sélection des } \\
\text { projets }\end{array}$ & $\begin{array}{l}\text { Moderate. Projects are assessed } \\
\text { against criteria, that are not published } \\
\text { at the MEF website. Projects included } \\
\text { in the budget are selected from a list } \\
\text { of assessed projects. }\end{array}$ & $\begin{array}{l}\text { Low. The projects' assessment } \\
\text { process does not systematically } \\
\text { involve a technical review of the } \\
\text { quality of the studies. There is a lack } \\
\text { of executable criteria. }\end{array}$ & $* * *$ \\
\hline 11 & $\begin{array}{l}\text { Protection des } \\
\text { investissements }\end{array}$ & $\begin{array}{l}\text { High. Investments are protected } \\
\text { under the institutional framework and } \\
\text { the budget documentation } \\
\text { incorporates total project costs. }\end{array}$ & $\begin{array}{l}\text { Moderate. While effectiveness will } \\
\text { only be perceptible with the full } \\
\text { implementation of information } \\
\text { systems, recent practices permit this } \\
\text { protection. }\end{array}$ & * \\
\hline 12 & $\begin{array}{l}\text { Disponibilité de } \\
\text { financements }\end{array}$ & $\begin{array}{l}\text { Moderate. The regulatory framework } \\
\text { provides for different programming } \\
\text { and management tools but allows the } \\
\text { option of external financing with } \\
\text { commercial banks. }\end{array}$ & $\begin{array}{l}\text { Moderate. Although funds are } \\
\text { disbursed in a timely manner, this } \\
\text { availability is undermined by the } \\
\text { absence of commitment plans and } \\
\text { external financing outside of the } \\
\text { treasury single account. }\end{array}$ & $* *$ \\
\hline 13 & $\begin{array}{l}\text { Transparence de } \\
\text { l'exécution }\end{array}$ & $\begin{array}{l}\text { High. The institutional framework } \\
\text { provides for open, transparent public } \\
\text { procurement, physical and financial } \\
\text { monitoring of projects, as well as ex } \\
\text { post external audits. }\end{array}$ & $\begin{array}{l}\text { Moderate. In fact, the absence of } \\
\text { traceability in procedures and } \\
\text { coordination between the players can } \\
\text { adversely affect transparency. }\end{array}$ & * \\
\hline 14 & $\begin{array}{l}\text { Gestion de la } \\
\text { mise en œuvre }\end{array}$ & $\begin{array}{l}\text { Moderate. While rules apply to } \\
\text { project management and assessment, } \\
\text { such rules do not reflect } \\
\text { improvements made to projects } \\
\text { during the process of execution. }\end{array}$ & $\begin{array}{l}\text { Moderate. Effective management is } \\
\text { complicated by weaknesses in the } \\
\text { information system and assessments } \\
\text { are still insufficiently focused on the } \\
\text { expected results. }\end{array}$ & $* *$ \\
\hline 15 & $\begin{array}{l}\text { Comptabilisation } \\
\text { des actifs }\end{array}$ & $\begin{array}{l}\text { Low. The institutional framework for } \\
\text { stock and accrual basis accounting } \\
\text { requires more detailed, operational } \\
\text { regulation. }\end{array}$ & $\begin{array}{l}\text { Low. The inventory of public assets is } \\
\text { conducted on a partial basis, the } \\
\text { information is not included on the } \\
\text { balance sheets, and there is no } \\
\text { amortization/depreciation. }\end{array}$ & $* * *$ \\
\hline 16 & Capacités & $\begin{array}{l}\text { Moderate. The regulatory framework, } \\
\text { which is being updated, incorporates } \\
\text { public investment requirements. } \\
\text { There is a need for staff capacity and } \\
\text { information technology } \\
\text { strengthening. }\end{array}$ & $\begin{array}{l}\text { Moderate. Lack of tools and } \\
\text { exchanges of information deny a } \\
\text { comprehensive monitoring of } \\
\text { projects from planning to execution. } \\
\text { Training plans should improve. }\end{array}$ & ** \\
\hline 17 & Marchés Public & $\begin{array}{l}\text { High. According to the legal } \\
\text { framework, the procurement process } \\
\text { should be open and transparent, } \\
\text { contracts be subject to physical and } \\
\text { financial monitoring in coordination } \\
\text { with the contracting authorities, and } \\
\text { be audited. }\end{array}$ & $\begin{array}{l}\text { Moderate. Public procurement } \\
\text { arrangements could be more } \\
\text { transparent, open, and effective; } \\
\text { timing delays may adversely affect } \\
\text { transparency and efficacy. }\end{array}$ & $* *$ \\
\hline 18 & Maintenance & $\begin{array}{l}\text { Moderate. Certain ministries have } \\
\text { rules and methodologies to assess } \\
\text { major projects' recurring costs. These } \\
\text { methodologies, however, are not } \\
\text { harmonized or consolidated. }\end{array}$ & $\begin{array}{l}\text { Low. Maintenance costs, when } \\
\text { assessed, are not systematically or } \\
\text { comprehensively included in the } \\
\text { budget. }\end{array}$ & $* * *$ \\
\hline
\end{tabular}




\section{PUBLIC INVESTMENT IN MALI: CONTEXT}

5. Public investment is a powerful leverage for public policy. Public investment provides users with infrastructures or public goods that support the operations of the government, and stimulate private investment. Public investments are financed by: the share of budget expenditure earmarked for gross fixed capital formation; and fixed capital accumulation from public agencies and enterprises (excluding merchant sector). When integrated into a sustainable economic policy approach, public investment ensures that community goods and services are provided consistently and that the country is economically attractive, while supporting growth.

\section{Public investment produces the stock of public fixed capital, which is an essential} component of production. Fixed capital includes all tangible and intangible assets earmarked for use in production processes for at least one year (durable goods). Gross fixed capital formation of government (i.e. the central and local governments) consists of the purchasing or production of fixed assets (capital goods, housing, buildings, etc.) acquired to be used for at least one year in processes to produce goods and services incorporated into the acquired capital, land, and intangible assets. In Mali, public gross fixed capital formation is estimated in the national accounting system as a derivative of capital expenditure incorporated into the state budget, adjusted to reflect expenditure not directly supporting the formation of durable assets. The stock of fixed capital is comprised of cumulative gross fixed capital formation, to which a long-term attrition rate is assigned.

\section{A. Patterns of Public Investment and Fixed Capital Stock}

\section{In Mali, public investment has a direct economic impact, and plays a leverage role.}

While public investment in 2015 represented only one fifth (20.8 percent) of total public and private investment combined (Figure 3), it has become an essential source of leverage to stimulate the country's investment. In addition to the normal operation of services, public investment policies aim to make the country more attractive to foreign investors by improving public capacities and networks, as well as the business climate. It also aims to promote domestic private investment through social housing programs and the accommodation of public services (including public health and education). This function to stimulate private investment has been late in coming. It has been fairly evident since 2002, the year when public and private investment cycles began to be synchronized (Figure 3). During the same period, the investment cycle began to correlate more closely with growth (Figure 4), which suggests that investment is effectively correlated with economic growth. 
8. The government of Mail has been attempting, with limited success, to generate domestic resources for public investment. The government would like to increase its capital expenditure (identified as equipment and investment expenditure in the state budget). This economic policy thrust has been particularly affirmed since the 2010s in connection with the IMF program supported by the Extended Fund Facility. The government's willingness has been regularly expressed in its memoranda addressed to the IMF Executive Board: (i) to increase its revenue to provide additional resources in the budget; and (ii) to devote these resources to expenditure in support of inclusive growth, in which investment was the key factor. These economic policy thrusts have had little, if any, effect on the composition of the budget (Figure 6). The share of capital expenditure in national resources in the budget remained at approximately 40 percent (roughly one half of fiscal revenue) during the period 2004-2015, with a particularly pronounced decline during the 2012 crisis when the authorities were forced to discontinue investment so that wages and other priority expenditure could be covered (Figure 5).

\section{Mali's development partners have provided substantial aid to support investment in} the country. Financial aid in support of Mali's development has included two main channels (budget support and project support): (i) sectoral or general budget support (10-20 percent of the financial aid from all donors combined) was paid to the national Treasury on a conditional basis and incorporated into the budget resources to be executed under Mali's domestic law; (ii) project aid (80-90 percent of the financial aid from all donors combined) was allocated to the execution of specific projects under agreements made between the government and the partner country or institution. The share of this project support in public investment has varied in the range of 20-50 percent. Its volatility from year to year has been largely due to cases of noncompliance with disbursement criteria and to procedural issues.

10. The financial efforts of the partners and government have produced volatile, downward-sloping gross fixed capital formation trends over time. The 25-year study of the public investment effort (public gross fixed capital formation) for Mali (Figure 3) features the following patterns: a steady decline in the share of public investment in GDP during the period; and the volatility of public investment efforts, with a standard deviation of 1.7 percent of GDP year on year. Moreover, Mali's public investment drifted downwards from, and has not caught up with the WAEMU's average since 2011. In 2015, Mali's lag behind the WAEMU average amounted to 4 percent of GDP. These trends can be explained by the increase in GDP during the period considered (with an average growth of 4.6 percent); a lower growth in public investment; volatile external financing; and the country's vulnerability to macroeconomic and geopolitical shocks, particularly in 2012.

11. Trends in fixed capital during the past 15 years fall short of economic and demographic growth. The stock of fixed capital represented approximately 110 percent of GDP in 2000 and less than 70 percent of GDP in 2015 (Figure 7). This trend in public fixed capital clearly fell short of economic growth. This a substantial erosion in public assets can be explained by hard geopolitical, climate, and environmental conditions and insufficient efforts to maintain and renew the country's existing infrastructures. The fixed capital stock per capita declined by approximately 17 percent between 2000 and 2015 (in constant U.S. dollars, subject to purchasing power adjustment, per capita). Accordingly, the stock of fixed capital per capita falls short of the levels observed in other WAEMU countries (Figure 8). 


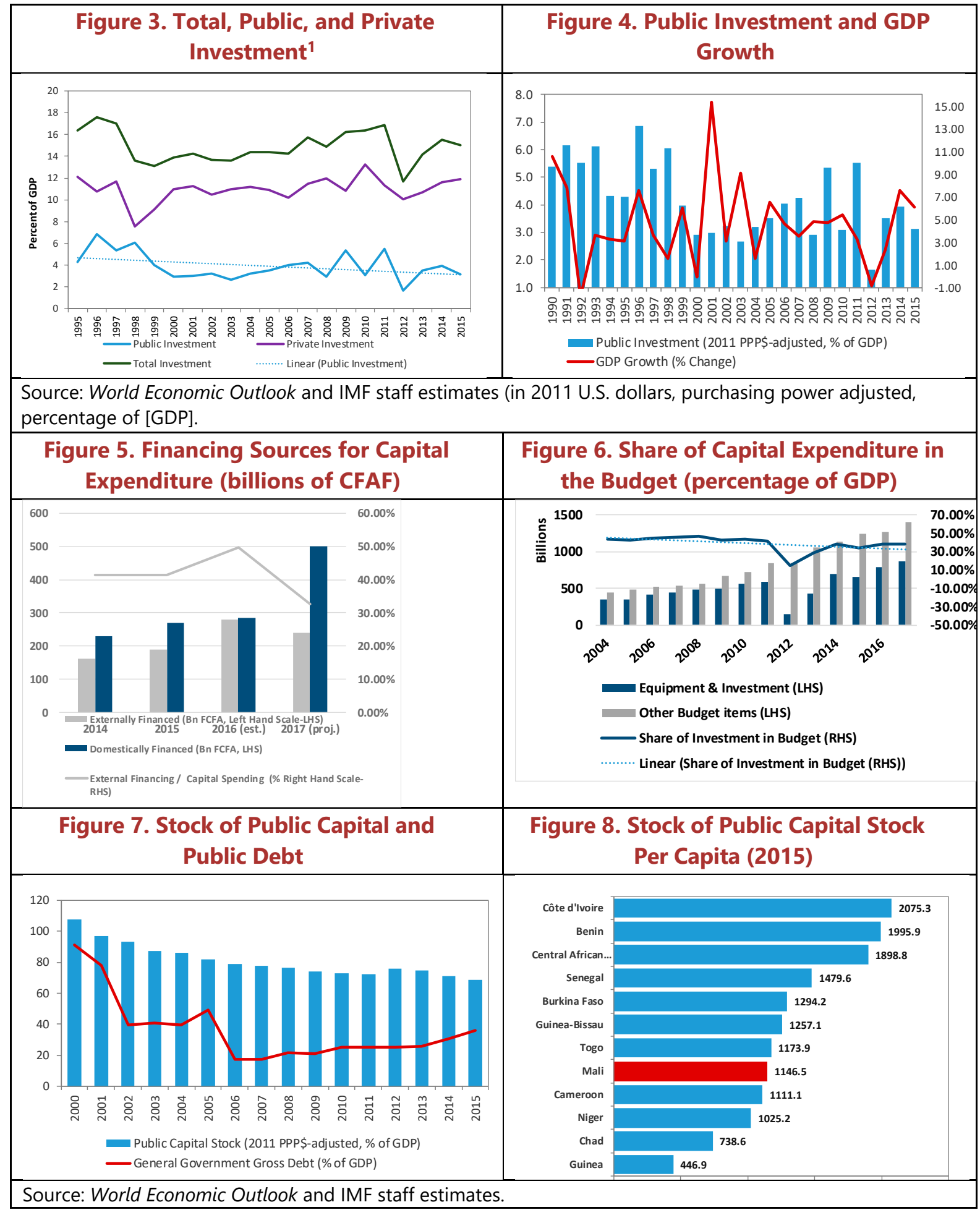

${ }^{1}$ Unless otherwise indicated: data in 2011 U.S. dollars, purchasing power adjusted, percentage of GDP. 
12. Against this backdrop, the ratio between the stock of fixed capital and public debt has eroded slightly, even though the debt has been largely kept under control (Figure 7). Since 2000, public debt has declined substantially as a result of cancellations granted by creditors at the beginning of the 2000s, from 91 percent of GDP (2000) to 17 percent (2006). The debt has since been brought, and kept down to levels of approximately 20-36 percent of GDP, clearly below the ceiling established by the WAEMU of 70 percent of GDP. In 2015, while the debt was assessed with a moderate risk of distress, the public debt / fixed capital ratio, however, had worsened: from 22 percent of fixed capital in 2005, to 53 percent in 2015 with a slight upward trend.

\section{B. Quality, Efficiency, and Impact of Public Investment}

13. Public investment is an essential component of development plans. The government of Mali has implemented development and poverty reduction plans, the objectives of which have correlated with the achievement of the millennium development goals. The latest plan to date, is the "strategic framework for economic recovery and sustainable development of Mali" (CREDD 2016-18). It aims to promote inclusive, sustainable development with a view to reducing poverty and inequalities in a unified, peaceful Mali, based on the country's potential and capacities for resilience, in order to achieve the sustainable development goals at the horizon 2030.

Approximately 40 percent of the projected expenditure under the CREDD (CFAF 3,440 billion) is devoted to investment, with emphasis on access to health and education infrastructures, drinking water, electricity, and improving access to landlocked parts of the country.

14. As a result of these development plans, access to public infrastructures has improved despite the attrition in public investment. Access to infrastructures is measured using a number of different indicators, as a proportion of the population: the number of teachers per thousand inhabitants, kilometers of road per thousand inhabitants, the number of hospitals per thousand inhabitants, and the percentage of the population that has access to drinking water. These indicators have improved in recent years, with the noteworthy exception of health (Figure 9). We can cite the following as some of the factors to explain this progress: the effects of decentralization (particularly to the municipalities) on grassroots level infrastructures, efforts to improve access, major hydro-agricultural programs, and the results of investment plans of major public enterprises and agencies.

\section{The quality of infrastructures, perceived as good as against other comparable} countries, has been on the decline since 2012. The quality of the country's infrastructures perceived by users has been assessed through surveys. ${ }^{2}$ Of course, this perception may vary over time for subjective reasons, as respondents may be more or less demanding from year to year. It is therefore important, for this criterion, to position Mali against comparable countries (Sub-Saharan Africa, developing countries, or other WAEMU member countries). Over a 10-year period, the quality of Mali's infrastructures has been quite similar to its comparators (Figure 10). Between 2010 and 2012, Mali was even above average in this connection. Unfortunately, the country's position has deteriorated since 2012, which suggests that fixed capital stock attrition is ultimately affecting the quality of the essential infrastructures.

\footnotetext{
${ }^{2}$ Data compiled by the World Economic Forum based on opinion surveys conducted by infrastructure sector in each country involved. The methodology and size of the panels vary depending on the sector.
} 
16. The IMF's calculations show that public investment efficiency levels are relatively low in Mali. The Public Investment Efficiency Index (PIE-X), is based on an aggregate measurement of infrastructure coverage and the perception of its quality. Against PIE-X, Mali is rated 0.57 on a scale of 0 to 1 (Figure 11), which is below the average of 0.64 for Sub-Saharan African countries and of 0.73 for emerging countries. As a result, Mali stands far from the efficiency frontier (Figure 10).

17. The efficiency gap reflects the insufficient volume and coverage of Mali's infrastructures rather than their quality, which is considered to be better than comparable countries. These findings in fact reflect a highly contrasting perception of Mali's infrastructures with:

- A good quality component (Figure 13) of 0.81 as compared with an average of 0.78 in emerging countries and 0.80 in Sub-Saharan African countries;

- A poor physical component of the indicator measured with access to infrastructures (Figure 14) of 0.32 , as against a world average of 0.59 and an average of 0.46 for Sub-Saharan African countries;

- A combined efficiency gap reflecting the two above components (Figure 12) of 0.43, as compared with 0.27 for other countries of the world.

\section{To sum it up: when spending on public investment, Mali does not get value for}

money. Inefficient management has led to considerable wastage of invested funds, while the capital budgets have declined over time, leading to a decline in gross fixed capital formation. Mali's position for the period $2015-2017$ is not an enviable one:

- Despite aid from Mali's partners, the country's investment effort (gross fixed capital formation) was insufficient and volatile;

- As a result of an extremely difficult natural and geopolitical environment, infrastructure assets deteriorated quickly owing to a lack of appropriate maintenance;

- Users deem that the quality of the country's infrastructures has been on the decline since 2012;

- Last, although access to essential infrastructures has improved during the past 25 years, the stock of fixed capital per capita is still at one of the lowest levels in the sub region.

${ }^{3}$ For further information on the definition and calculation of the PIE-X indicator, see the IMF Executive Board Paper "Making Public Investment More Efficient," published in June 2015. 


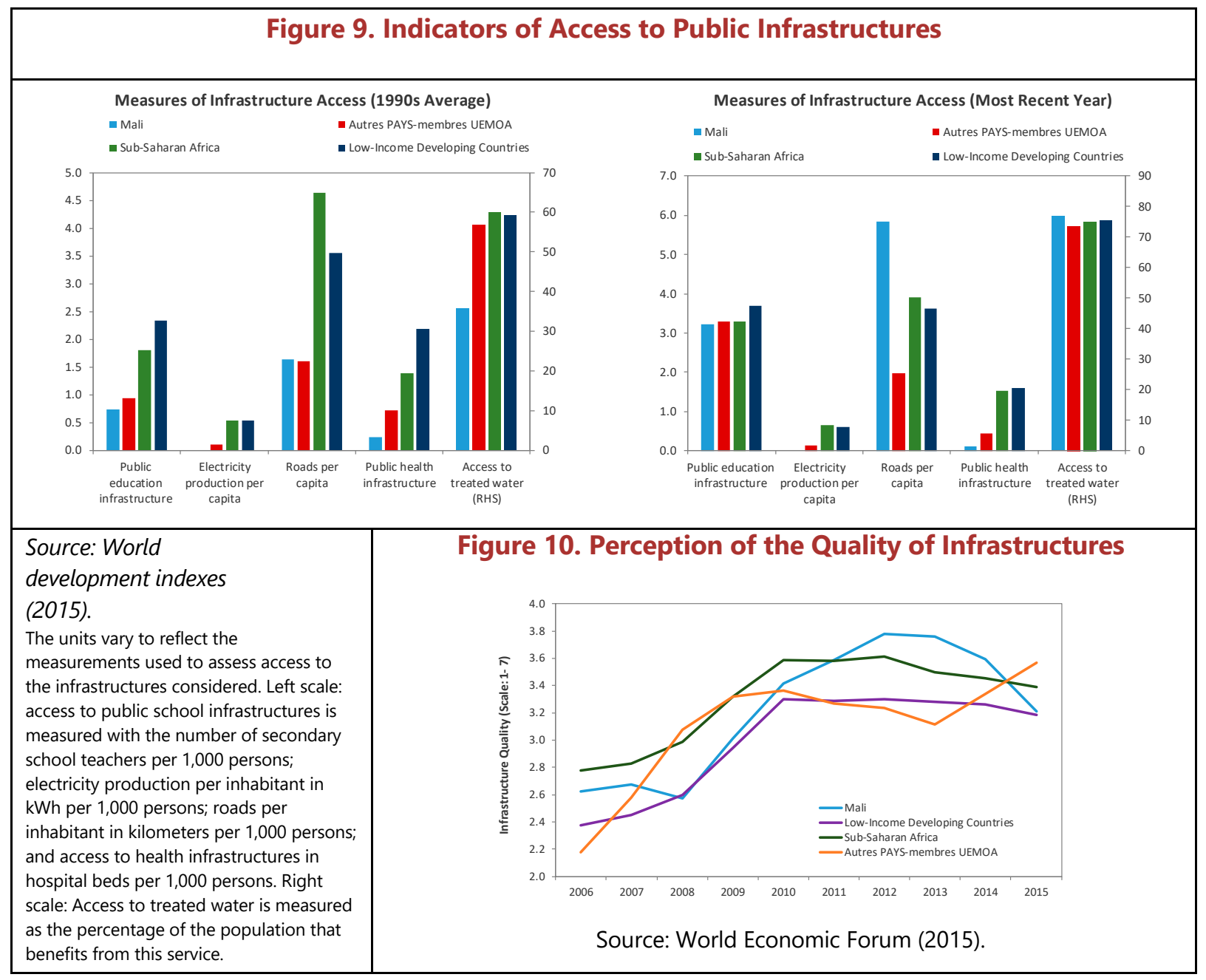




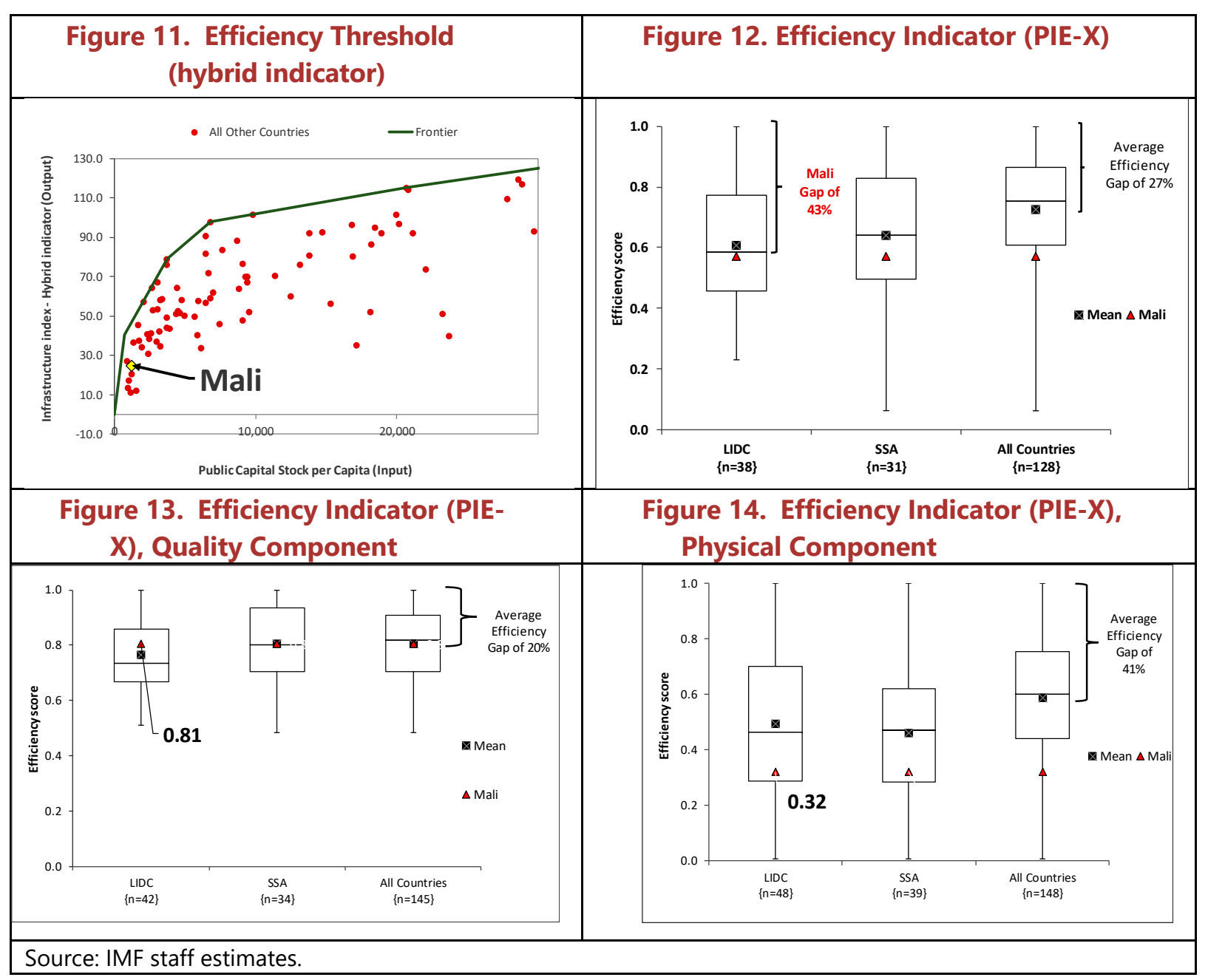




\section{PUBLIC INVESTMENT MANAGEMENT ASSESSMENT}

19. This section presents the results of the PIMA for Mali (see Box 1 for the methodology and Annex 1 for the detailed listing of criteria and scores). The three pillars of the public investment management assessment (planning, allocation, and execution) are examined in succession, followed by cross-cutting issues. For each practice, a table lists the institutional strength ${ }^{4}$ with scores obtained in two areas: first, the institutional framework (based on existing regulations, decrees, and laws) and second, its effectiveness (based on an assessment of its implementation). The table also indicates the level of priority of the reforms to be conducted (with asterisks).

\section{Overall findings}

20. The institutional strength of the management framework for public investment is good when considered against comparable countries. The assessment of 15 institutions (or components) of the management framework brings to light generally good scores at or above average levels for LICs in almost all components. However, we observe four exceptions:

1. The institutional framework applicable to public private partnerships (PPPs) is incomplete. While the country has already accumulated just over 3 percent of GDP in fixed capital through the PPPs (public service concessions), the legal framework was not established by law until 2016. The unit specialized in public-private partnerships (PPPs), which reports to the Prime Minister, has yet to become operational.

2. There is scope for improvement in the accounting and valuation of assets, and particularly non-financial assets. This function will be addressed in further detail in connection with the reforms in progress. Pending this progress, stock accounting and general accounting systems are not comprehensive or consistent.

3. The availability of investment funds is still unstable. Even if Mali is not accumulating payment arrears, management is still adversely affected by commitment and cash flow projections with scope for improvement.

4. Last, project assessment is not systematic or thorough. These activities focus more on indicators than on expected socioeconomic results.

${ }^{4}$ To ensure that the concepts are clear, we consider "institutional strength" of public investment management to be a component of the quality of the "institutional framework" and of the "effectiveness" of its implementation. 


\section{A number of reforms will improve the institutional strength of public investment}

management. Departures from good practices reported in this public investment management assessment are in the process of being addressed while authorities are implementing the regional directives of the West African Economic and Monetary Union (WAEMU). All reforms aimed at implementing program budget, commitment control, accrual-basis accounting, and the treasury single account could improve Mali's public investment management framework, which is relatively robust and in general is effectively implemented, albeit somewhat formally, by managers. Last, there is hope that the implementation of results-based management will change administrative culture from the formal application of the framework to a more performancedriven approach. 


\section{Box 1. Public Investment Management Assessment Framework (PIMA)}

IMF staff have developed a public investment management assessment framework. This framework is designed to assess the quality of the institutional framework in the relevant texts and in practice in order to help the countries optimize their public investment to achieve the objectives of growth and development. The PIMA identifies the strengths and weaknesses of the institutions and provides support along with practical recommendations to strengthen and increase the efficiency and impact of public investment.

The tool assesses 15 practices (known as "institutions") involved in the three main stages of the public investment cycle (see Figure below):

- Planning of the levels of investment for all public-sector entities to ensure sustainable public investment levels;

- Allocation of investments to appropriate projects and sectors;

- Execution of projects in time and allocated credits.

For each of these 15 institutions, three indicators are analyzed and assigned a score to determine whether the criterion is fully, partially, or not met. The average score is used to determine the institutional strength of each institution, which may be high, moderate, or low.

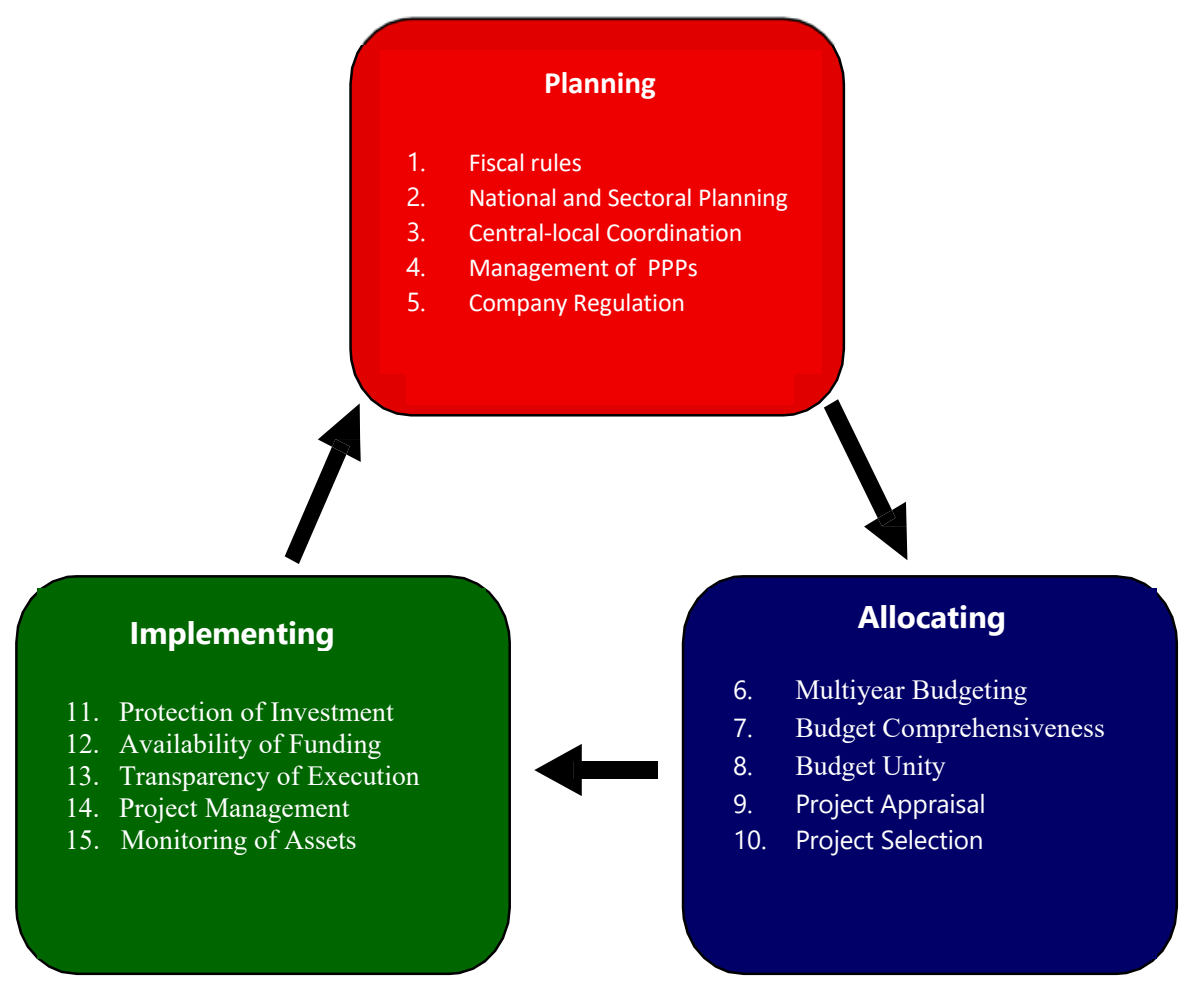




\section{A. Pillar l: Planning}

22. Effective planning can support the sustainability of public investments and the coordination of development strategies. This component of the PIMA is used to determine whether Mali has (i) fiscal principles or rules to preserve investment; (ii) national and sectoral plans defining investment strategies; (iii) effective coordination between central and local administrations in the area of investment; (iv) transparent management of PPPs; and (v) regulation of infrastructure enterprises to promote competition.

\section{The effectiveness of the institutional framework for public investment planning is} insufficient for entities outside of the Mali central government. The current institutional framework is sound and complete, with the noteworthy exception of PPPs and infrastructure enterprises. There is clearly scope for improvement in its implementation for all entities not directly under the central government. Accordingly, the reforms designed to operationalize the PPP unit, to optimize public sector infrastructure supply, and, most importantly in the context of decentralization, to manage and stimulate local investment, are important matters. The institutional strengths and weaknesses of the planning framework are indicated in Table 2 below.

Table 2. Summary Assessment, Pillar I

\begin{tabular}{|c|c|c|c|c|}
\hline \multicolumn{2}{|c|}{ Stage/Institution } & \multirow{2}{*}{$\begin{array}{l}\text { Institutional framework } \\
\text { Moderate. The permanent fiscal rules no } \\
\text { longer specifically apply to capital expenditure. }\end{array}$} & \multirow{2}{*}{$\begin{array}{l}\text { Effectiveness } \\
\text { High. The level of capital expenditure } \\
\text { is preserved while debt is limited to } \\
\text { the ceilings established by the } \\
\text { WAEMU. }\end{array}$} & \multirow{2}{*}{$\begin{array}{l}\text { Priority } \\
\text { of the } \\
\text { reforms } \\
\qquad *\end{array}$} \\
\hline 1 & Budget rules & & & \\
\hline 2 & $\begin{array}{l}\text { National and sectoral } \\
\text { planning }\end{array}$ & $\begin{array}{l}\text { High. The three-year investment plan, which is } \\
\text { published, breaks the national investment } \\
\text { strategy down by sector. Preparation of the } \\
\text { three-year investment plan is based on an } \\
\text { ascending partnership process. }\end{array}$ & $\begin{array}{l}\text { High. Sectoral and national strategies } \\
\text { are properly coordinated, reviewed } \\
\text { every year, and consolidated into a } \\
\text { unified document that presents the } \\
\text { key indicators for economic activity } \\
\text { and impact for each sector. }\end{array}$ & * \\
\hline 3 & $\begin{array}{l}\text { Coordination between } \\
\text { the central authorities } \\
\text { and local governments }\end{array}$ & $\begin{array}{l}\text { High. Recourse to borrowing for investment by } \\
\text { local governments is limited by law. The } \\
\text { amount of transfers is known more than six } \\
\text { months before the beginning of the fiscal year. } \\
\text { Planning is coordinated on a concerted basis. }\end{array}$ & $\begin{array}{l}\text { Low. The financial and operational } \\
\text { role of local governments in the } \\
\text { financing efforts is practically very low. }\end{array}$ & $* * *$ \\
\hline 4 & $\begin{array}{l}\text { Public-private } \\
\text { partnerships }\end{array}$ & $\begin{array}{l}\text { Moderate. The } 2016 \text { Law on PPPs is in the } \\
\text { process of implementation. It does not provide } \\
\text { a general definition of PPPs and does not } \\
\text { impose the principle of a ceiling on multiyear } \\
\text { guarantees or commitments. Monitoring of } \\
\text { financial commitments in connection with PPPs } \\
\text { is not organized. }\end{array}$ & $\begin{array}{l}\text { Low. PPPs undertaken prior to } 2016 \\
\text { have not been subject to preliminary } \\
\text { studies. Financial commitments are } \\
\text { not systematically recorded. }\end{array}$ & $* * *$ \\
\hline 5 & $\begin{array}{l}\text { Regulation of } \\
\text { infrastructure } \\
\text { enterprises }\end{array}$ & $\begin{array}{l}\text { Moderate. Major economic infrastructure } \\
\text { contracts undergo international and national } \\
\text { competitive bidding procedures. These } \\
\text { contracts are regulated by independent } \\
\text { authorities, and prices are unrestricted, except } \\
\text { for electricity. Surveillance of public } \\
\text { infrastructure enterprises in insufficient. }\end{array}$ & $\begin{array}{l}\text { Low. Because of insufficient structured } \\
\text { surveillance, investment plans of } \\
\text { public enterprises are not reviewed by } \\
\text { government staff. Financial risks in } \\
\text { connection with enterprises' } \\
\text { investment operations are not } \\
\text { monitored in a consolidated report. } \\
\end{array}$ & $* * *$ \\
\hline
\end{tabular}


Fiscal rules

24. The fiscal rules applicable to Mali are based on the WAEMU convergence indicators and do not specifically target capital expenditure. As a WAEMU member country, Mali applies the Union's convergence criteria established under a 1999 directive, as updated in 2015. These rules are implemented in the multiyear budget and economic programming paper (DPEBP) in which the three-year macroeconomic framework exercise is presented. The first and second tier criteria therefore cover the key economic indicators (See Table 3). Until 2015, they included a second-tier criterion aiming for the ratio of investments financed with domestic resources to tax revenue to exceed 20 percent. This criterion was eliminated in 2015, as well as in the Economic Community of West African States (ECOWAS). There is no high level permanent fiscal rule applicable to capital expenditure.

Table 3. Trends in WAEMU Convergence Indicators for Mali

\begin{tabular}{llrrrrr} 
& Normes & $\mathbf{2 0 1 2}$ & $\mathbf{2 0 1 3}$ & $\mathbf{2 0 1 4}$ & $\mathbf{2 0 1 5}$ & $\mathbf{2 0 1 6}$ \\
\hline First-tier criteria & & & & & & \\
Overall fiscal balance/GDP & $>=-3 \%$ & -0.9 & $-2,3$ & $-2,8$ & $-2,3$ & $-3,7$ \\
$\begin{array}{l}\text { Inflation rate } \\
\text { Outstanding public debt }\end{array}$ & $<=3 \%$ & 5,3 & $-0,6$ & 0,9 & 1,5 & $<3,0$ \\
balance/GDP & $<=70 \%$ & 24,3 & 26,4 & 27,3 & 31,3 & 30,3 \\
Second-tier criteria & & & & & & \\
Wage bill/tax revenue & $<=35 \%$ & 38,4 & 36,1 & 35,2 & 33,1 & 32,8 \\
Tax pressure & $>=20 \%$ & 11,9 & 12,3 & 12,5 & 14,0 & 14,7 \\
GDP growth rate (percent) & & $-0,8$ & 2,3 & 7,0 & 6,0 & 5,3 \\
\hline
\end{tabular}

Source: WAEMU Commission, National Economic Policy Committee, Mali.

25. However, a number of measures that are recent or currently being implemented are designed to protect capital expenditure. Since 2015, steps have been taken to limit operating expenditure and maintain investment levels. Moreover, in the WAEMU harmonized public financial management framework, budgeting of capital expenditure under commitment authorizations, scheduled to be fully implemented with effect from the 2018 fiscal year, should help make budget commitments in connection with such expenditure more reliable and sustainable by placing these items in a multiyear context. A presentation of budget appropriations identifying commitment authorizations and payment allocations has been appended to the budget law on an informational basis since 2016.

26. While gradually strengthening capital expenditure during the recent period, Mali is keeping its debt under control. The amount of capital expenditure, including items financed directly by the state, has been on a steady increase since 2013, from CFAF 389.6 billion in 2013 (6 percent of GDP) to CFAF 740 billion in 2016 (8.9 percent of GDP). This investment effort has been accompanied with an increase in public debt, which is still limited, making it possible to keep debt within the WAEMU convergence criteria. Accordingly, public debt represented 30.5 percent of GDP in 2016, as against 26.4 percent in 2013. This stock of public debt is deemed to be sustainable with a moderate risk of debt distress. 
Figure 15. Comparative Developments in Public Debt and Capital Expenditure (as a percentage of GDP)

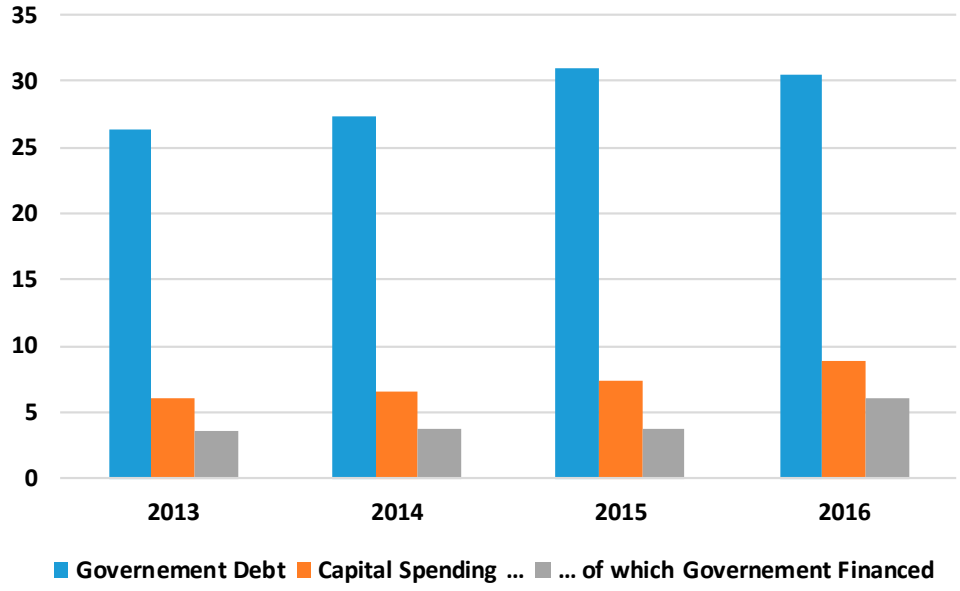

Source: Mission, according to IMF data.

\section{National and sectoral planning}

\section{The national investment strategy is defined by the strategic framework for} economic recovery and sustainable development (CREDD) and is broken down by sector in the three-year investment plan. Mali's CREDD covers the period 2016-2018 and constitutes the reference paper for development strategies and policies, in connection with the sustainable development goals adopted in September 2015 by the international community. Infrastructure development is one of the listed priorities of the strategic area of promoting inclusive, sustainable growth in the strategic framework. These strategic guidelines are used as a basis for preparing the three-year investment plan published as an attachment to the Budget Law. The PTI is a sliding three-year plan. It presents a breakdown of planned projects, by sector and ministry. It presents the costs in connection with each investment project. These $s$ are part of the macroeconomic framework for implementation of the CREDD. Last, sectoral programming defined in the PTI is reflected in the medium-term expenditure frameworks.

\section{The development of national and sectoral strategies is effectively coordinated}

based on a bottom-up and participative process. The CREDD was produced based on a series of consultations with all stakeholders. At the sector level, the process of preparing the three-year investment plan is defined on an annual basis in a circular letter from the minister responsible for planning. Accordingly, the strategic planning units (CPS) lead the discussions for each sector, which can include several ministries and involve players at the central government level. These units are responsible for ensuring that feedback expressing requirements at the sector level moves up to the National Development Planning Directorate (DNPD) so that it can be reflected in the three-year investment plan. In practice, not all strategic planning units make the required pre-selection between ministries' raw projects before submitting them to the DNPD. However, the sectors' priorities are properly integrated into the three-year investment plan and the various strategies are properly coordinated. Similarly, performance contracts established between the ministries and agencies under their authority can be used to coordinate investment strategies. 


\section{The national and sectoral strategies are subject to annual monitoring based on}

measurable impact and activity indicators and objectives. The CREDD has a monitoring and assessment system designed to indicate the status of the strategy at the national level. Annual reviews are also conducted at the sector level to monitor the status of projects. The adopted indicators combine monitoring of activities and results, as required (see examples below).

\section{Table 4. Examples of Sectoral Strategic Indicators}

\begin{tabular}{ll} 
Sector & Indicators \\
Energy & Rate of access to electricity, national level (percent) \\
& Rate of access to electricity, urban areas (percent) \\
& Rate of access to electricity, rural areas (percent) \\
\hline Roads & Length of maintained paved roads \\
& Length of paved roads in good condition \\
\hline Rail transportation & Ton per kilometer \\
& Passenger per kilometer \\
& Number of passengers \\
& Total cargo \\
\hline Education & Gross school enrollment rate, junior secondary education (in percent) \\
& Gross school enrollment rate, junior secondary education, girls (in percent) \\
& Enrollment rate, junior secondary education (in percent) \\
& Completion rate, junior secondary education (in percent) \\
& Percentage repeaters, junior secondary education (in percent) \\
& Gross school enrollment rate parity index, girls/boys \\
& Ratio of students to teachers, junior secondary education
\end{tabular}

Source: Mission, according to the 2015 Report on national strategy implementation.

\section{Coordination between the central government and local governments}

30. Local government borrowing is legally limited to investment financing. Compliant with article 227 of Law 2012-007 of February 7, 2012 establishing the legal framework for local governments, local budgets may include authorized loans, only if earmarked to investments. Moreover (cf. article 216) local governments may levy specific taxes earmarked to capital expenditure. This tax's rate is then set by the representative of the Central Government, after consultation with the president of the local executive.

31. Local governments' investment plans are designed in coordination with the central government. The economic, social, and cultural development program (PDSEC) constitutes the reference framework for investment projects of the local governments. This program has been implemented since 2015 through plan contracts between the central government and the regions. It targets structuring investments that create jobs and wealth as a priority. Frameworks for cooperation and coordination also exist for coordination of development activities at different levels: the national steering committee for technical support to the local authorities (CNO); regional committees for steering, coordination, and monitoring of development activities (CROCSAD); local committees for steering, coordination, and monitoring of development activities (CLOCSAD); and municipal committees for steering and coordination of development activities (CCOCSAD). 
32. The amount of transfers to local governments for capital expenditure is generally known at least six months before the beginning of the fiscal year. In 2007, Mali established a National Fund to Support the Regional Units of Government (FNACT), supported primarily by donors, and partially with transfers from the central government budget. This fund is managed by the National Investment Agency for Local governments (ANICT). For the allocation of investment subsidies, the ANICT uses a cross subsidization formula that combines two series of criteria: (i) background criteria (specific needs of local governments with respects to their territorial context); and (ii) performance criteria (effectiveness of the local taxation system). Each year, the ANICT provides the local governments a fiscal framework with the planned amount of transfers from central government. In 2016, this framework was issued on June 9.

\section{In practice, the local governments still play an insufficient role in the investment} effort, for both financial and technical reasons. Both the financing and the execution of local investment are highly dependent on support from the state. The central government budget is the main source of financing for the local governments whose own resources are insufficient, e.g. since 2007, the local governments' own revenue has been continuously insufficient (particularly nontax revenue). Moreover, the central government operates a substantial share of capital expenditure locally, through its decentralized units, and multiregional projects.

\section{Figure 16. Composition of Investment Resources in Local Governments}

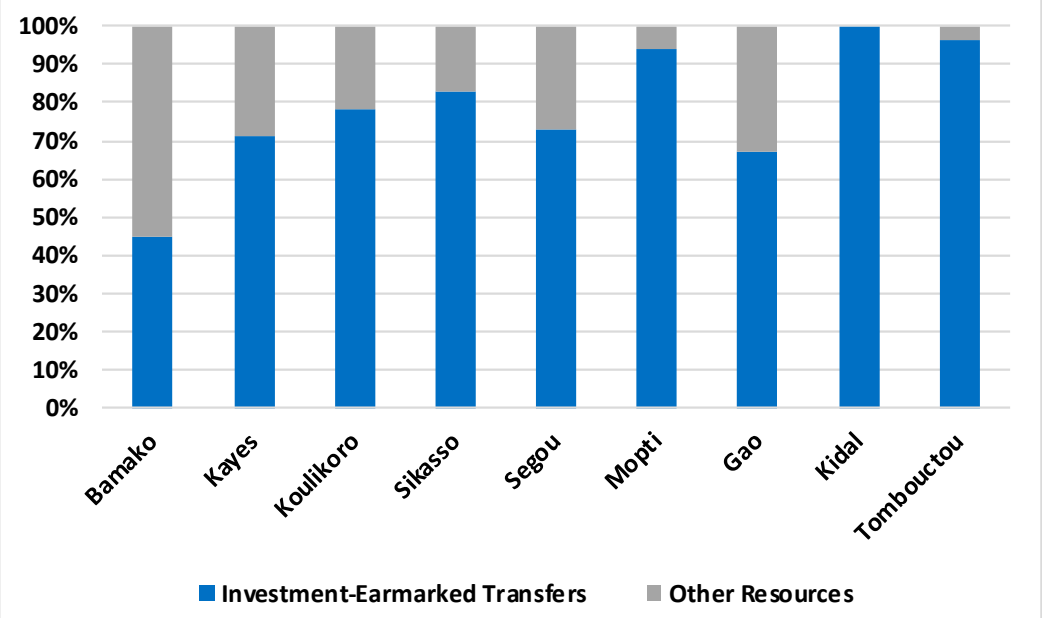

Source: DNTCP, management accounts, aggregate units of government at the regional level for the 2015 fiscal year.

34. There is a scarcity of funds for capital spending in local governments' budgets. According to the data provided for the public expenditure and financial accountability (PEFA) assessment in 2016, capital expenditure amounted to CFAF 27.4 billion, equivalent to 14 percent of total expenditure in the budgets of the local governments. Although this share has more than doubled in three years (see Figure 17), it is still limited substantially by the shortage of local governments' own resources and their dependence on the state's budget. 
Figure 17. Share of Operating and Capital Expenditure in Local Budgets

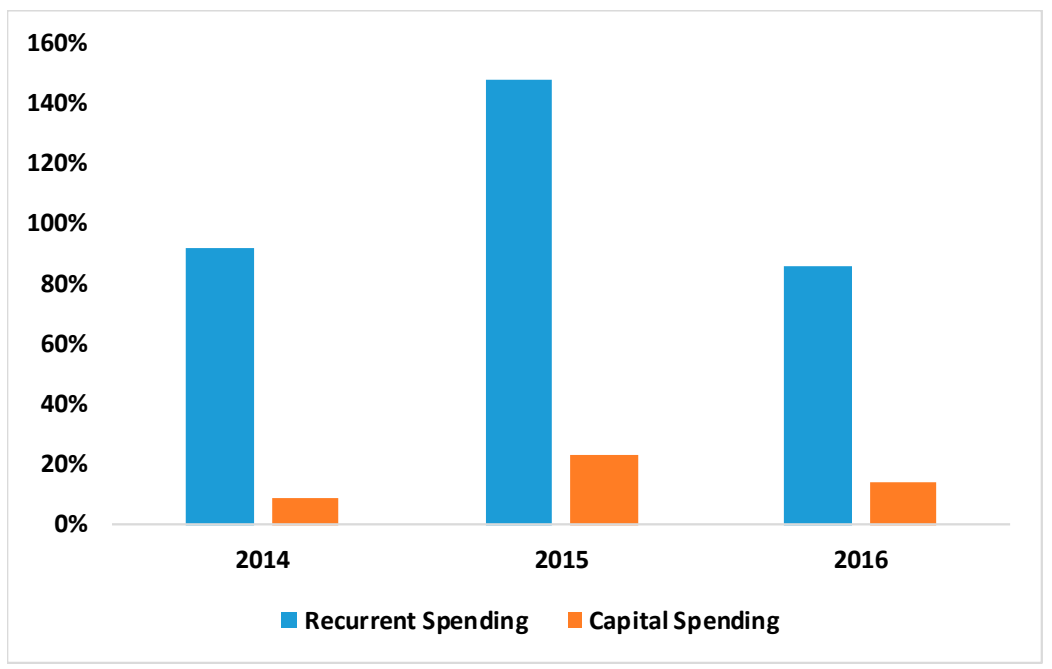

Source: PEFA Report, 2016.

Public-private partnerships (PPPs)

35. The legal framework for PPPs is recent, it comprises the Law 2016-061 of December 30, 2016 and the Decree of February 9, 2017. While the law does not provide a general definition of PPPs, it lists the types of contracts that are considered PPPs: concessions (for works or services), concessions of general interest involving, or not public service delivery; third-party management, combined contracts, and partnerships involving payment from the government. The law also provides for the establishment of a PPP unit responsible for providing expertise during the various stages of the process. In line with good practices, PPP contracts are subject to prior approval and budget sustainability check by the minister of economy and finance.

\section{Some good practices are not, however, reflected in the law or its sub-regulations:}

- Introduction of the principle of a ceiling on financial commitments or guarantees for PPPs from the public sector;

- Indication of the risks that the private partner must undertake so that the contract does not entail excessive risks for the public party;

- Incorporation of the rate of return on investment for the private operator among the criteria for awarding PPPs and in the compulsory clauses of the contract;

- The vote by Parliament on the commitment authorization for PPPs beginning with the first year of implementation (see Organic Law on Budget Laws-LOLF) and the requirement to make all PPP contracts public (see governance decree).

37. Moreover, the law introduces waiver options that should be strictly defined and made more restrictive in the implementing decrees: 
- The law excludes from the procedure spontaneous offers and contracts executed according to the direct negotiation procedure as the result of an emergency deriving from unforeseeable circumstances;

- While the law establishes the general principle of transparency in PPP contracts and the use of competitive bidding procedures, it allows opportunities to bypass these procedures through restricted bidding and negotiated mechanisms;

- The law provides the option for the private partner to receive an indemnity should the economic balance of the contract be disrupted by unforeseeable events. This provision could lead to numerous, costly contract renegotiations.

38. PPPs concluded before the establishment of the PPP framework, by end-2016, have not undergone any PPP-specific appraisal. The law specifies that an evaluation process including the following assessments must be conducted before any procedure kickstarts: (i) an analysis demonstrating the economic and social utility of the project, as well as a positive environmental impact; (ii) an analysis showing that executing the project under a PPP is more profitable for the government than using other public procurement mechanisms; (iii) a budget sustainability analysis assessing the project's fiscal impact, the availability of funds, and, if applicable, its compatibility with the government property policies on real estate. A number of contracts consistent with the definition of PPPs now provided under the law were executed prior to 2016: Transrail (railroad), Ozone (sanitation), a zoo, Mali Technique Système (technical vehicle inspection), Mali Plaques (production of vehicle license plates), Énergie du Mali (electricity), and SOMAGEP (drinking water distribution). These PPP-like contracts, then processed like regular projects yielded a noteworthy stock of capital (see Figure 18).

\section{While the PPP unit is becoming operational, there is a need to foster its} coordination with the MEF for fiscal monitoring on PPPs. The PPP Unit was established under the authority of the Prime Ministry in February 2017 following publication of the decree specifying its missions including: technical assistance and expertise, validation of preliminary assessments, opinions on draft contracts, and participation in project monitoring. At the same time, the MEF must play an essential role in identifying, assessing, and monitoring budget sustainability and any liabilities in connection with PPPs. However, at this point, no structure or procedure has been established with the MEF to monitor PPP costs or mitigate PPP budget risks. There is a need to set-up mechanisms for communication, and information exchange between the PPP Unit and the MEF to best address fiscal risks when they are about to materialize 
Figure 18. Stock of Capital in Connection with PPPs in Mali as Compared with Other Countries of Francophone Africa

(percentage of GDP)

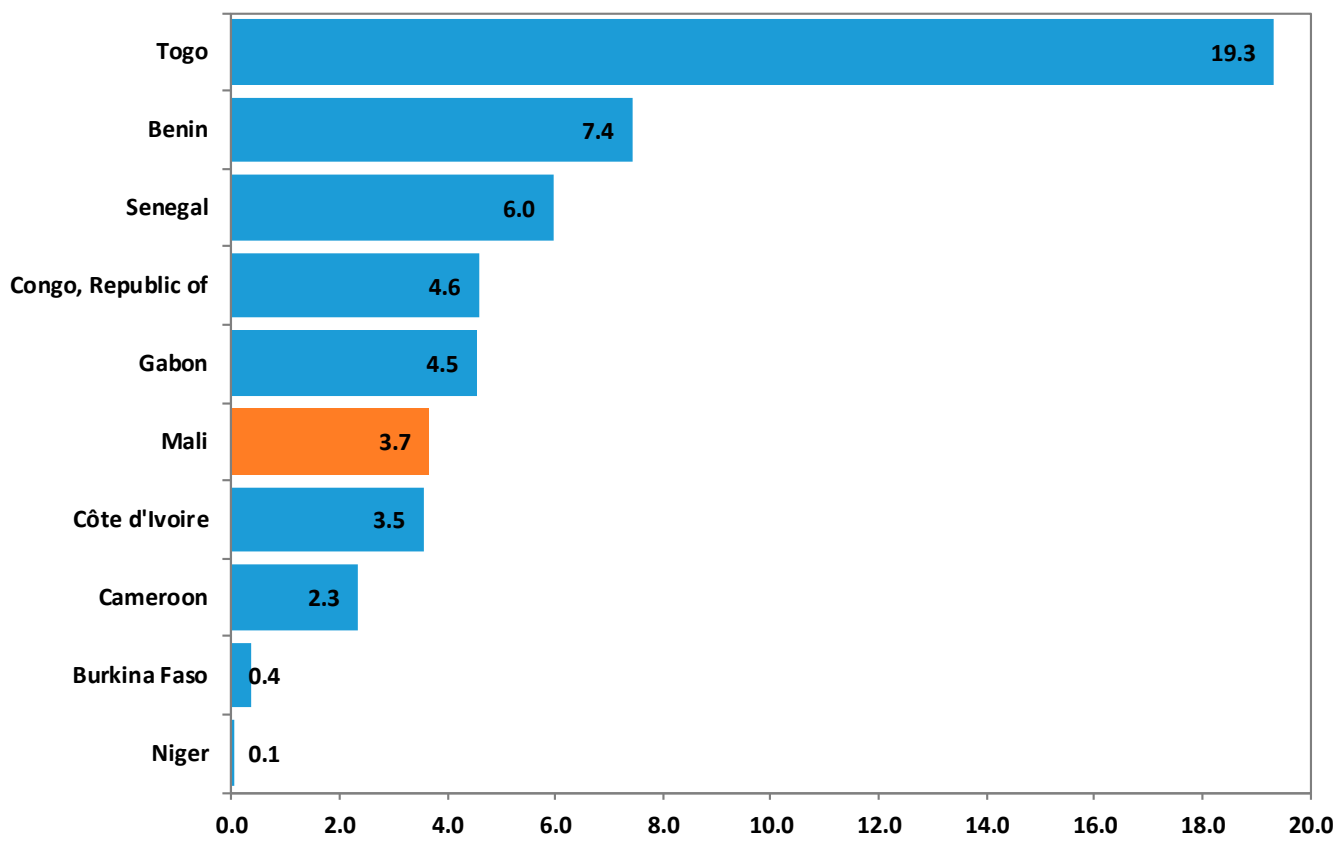

Source: World Economic Outlook, staff calculations.

Regulation of infrastructure enterprises

40. Major economic infrastructure contracts are subject to international and domestic bidding procedures, and service prices are freely established. Legally, the markets for water, electricity, telecommunication, and transportation services are fully open to competition. However, in practice, there is a de facto monopoly on the electricity production market. While independent authorities are involved in regulating these markets, prices are freely determined, with the exception of those for electricity distribution. 
41. Surveillance of public infrastructure enterprises is still insufficient. The state wholly or partially owns 52 public enterprises (including five public industrial and commercial establishments). This portfolio is monitored by the Directorate General of Government Asset Management (DGABE). Each year by June, the DGABE sends questionnaires to collect financial information on public enterprises and to store it on a data base. However, approximately one third of the questionnaires are not responded to. The consolidated assets of public enterprises amounts to CFAF 62.5 billion, equivalent to 1.5 percent of GDP. The data consolidated by the DGABE is forwarded to the technical oversight authorities, yet not used by the Directorate General of Budget. Moreover, except for the five public industrial and commercial establishments having a performance contract with the state, the investment plans of public enterprises are not subject to review by the government. Thereby it is not possible to ensure enterprises' investment plans are: (i) complying with priorities set in the government three-year investment plan, and (ii) not entailing fiscal risks. To date, only Électricité $d u$ Mali is subject to specific financial surveillance, in the context of the program with the IMF which requires this enterprise's financial reports be issued quarterly. Although the Directorate General of Budget has plans to develop the analysis of budget risks related with public enterprises, this function is yet to be developed.

Pillar I. Key Departures from Best Practices

\begin{tabular}{c|l|l} 
Institution & Ecarts & Importance \\
\hline 4 & $\begin{array}{l}\text { There is no concept of a ceiling on financial commitments or } \\
\text { guarantees from the public sector for PPPs } \\
\text { Insufficient coordination between the Ministry of Economy and } \\
\text { Finance and the PPP Unit } \\
\text { Insufficient financial surveillance for PPPs and public enterprises } \\
\text { Failure to report financial information between the Directorate } \\
\text { General of Budget, the Directorate-General of Government Asset } \\
\text { Management, oversight ministries, and public enterprises } \\
4 / 5\end{array}$ & $\begin{array}{l}\text { Insufficient financial analysis capacities for PPPs and public } \\
\text { enterprises } \\
\text { No consolidation of contingent liabilities } \\
\text { Insufficient capacities and resources for regional governments }\end{array}$ \\
3
\end{tabular}

\section{B. Pillar Il: Allocating}

42. This section presents strengths and weaknesses of institutions responsible for allocating proper resources to actual needs. It assesses whether Mali: (i) conducts multiyear budgeting with transparent and predictable appropriations for investment; (ii) issues a comprehensive budget, so that all public investments are included in the budget documentation, and are Parliament-authorized; (iii) implements a unified budget process; (iv) conducts ex ante project assessments; and (v) implements a project selection system. 


\section{The quality of the institutional framework for allocation of public investment is}

fairly good, although there is scope for improvement in project management. The quality of multiyear programming and budgeting processes for investments is good as compared with other WAEMU countries, even if many externally financed projects do not go through national procedures. There is room for improvement in project management, and specifically in selection and assessment processes, which have not been properly implemented. These shortcomings in project management can explain the inefficiency of public investment (as indicated above in Part I, Figure 14. Efficiency Indicator - Physical Component).

Table 5. Summary Assessment, Pillar II

\begin{tabular}{|c|c|c|c|c|}
\hline \multicolumn{2}{|c|}{ Stage/Institution } & \multirow{2}{*}{$\begin{array}{l}\text { Institutional framework } \\
\text { High. Capital expenditure of the } \\
\text { ministries is subject to multiyear } \\
\text { programming and ceilings to reflect all } \\
\text { project costs, and is published. }\end{array}$} & \multirow{2}{*}{$\begin{array}{l}\text { Effectiveness } \\
\text { High. Although program budget } \\
\text { implementation will not be effective } \\
\text { until } 2018 \text {, the multiyear programming } \\
\text { system is consistent. }\end{array}$} & \multirow{2}{*}{$\begin{array}{l}\text { Priority } \\
\text { of the } \\
\text { reforms } \\
\qquad *\end{array}$} \\
\hline 6 & $\begin{array}{l}\text { Multiyear } \\
\text { programming }\end{array}$ & & & \\
\hline 7 & $\begin{array}{l}\text { Comprehensiveness } \\
\text { of the budget }\end{array}$ & $\begin{array}{l}\text { Moderate. While capital expenditure is } \\
\text { generally executed in line with the } \\
\text { budget, the Budget does not contain } \\
\text { any information on PPPs. }\end{array}$ & $\begin{array}{l}\text { Moderate. Recording of externally- } \\
\text { financed capital expenditure is not } \\
\text { complete. Transactions of PPPs are not } \\
\text { monitored. }\end{array}$ & * \\
\hline 8 & Budget unity & $\begin{array}{l}\text { Moderate. The budget is prepared } \\
\text { with an economic, administrative, and } \\
\text { functional nomenclature. There is a } \\
\text { presentation by program appended to } \\
\text { the Budget Law. }\end{array}$ & $\begin{array}{l}\text { Moderate. Transition to the program } \\
\text { budget is planned for } 2018 . \\
\text { Investment-related recurring } \\
\text { expenditure is recorded in the budget, } \\
\text { but not disaggregated by project. }\end{array}$ & $* *$ \\
\hline 9 & $\begin{array}{l}\text { Ex ante project } \\
\text { assessment }\end{array}$ & $\begin{array}{l}\text { Moderate. The process for investment } \\
\text { project preparation includes ex ante } \\
\text { assessment. The assessment } \\
\text { methodology is under review. }\end{array}$ & $\begin{array}{l}\text { Low. Major structuring projects are not } \\
\text { systematically subject to a cost-benefit } \\
\text { analysis using a standard } \\
\text { methodology. The risk analysis is still } \\
\text { limited. }\end{array}$ & $* * *$ \\
\hline 10 & Project selection & $\begin{array}{l}\text { Moderate. Projects are assessed } \\
\text { against criteria, that are not published } \\
\text { at the MEF website. Projects included } \\
\text { in the budget are selected from a list } \\
\text { of assessed projects. }\end{array}$ & $\begin{array}{l}\text { Low. The projects' assessment process } \\
\text { does not systematically involve a } \\
\text { technical review of the quality of the } \\
\text { studies. There is a lack of executable } \\
\text { criteria. }\end{array}$ & $* * *$ \\
\hline
\end{tabular}

\section{Multiyear programming}

\section{Budget ceilings, with actual and comprehensive costs have been introduced in} Multiyear frameworks. Documents ${ }^{5}$ issued and published by the units in charge of multiyear programming are both complementary and consistent.

- The Medium Term Economic and Fiscal Framework (DPEBP) for 2017-19 will be submitted to Parliament during the FY 2018 budget pre-debate;

- Volume I of the program budget appended to the 2017 Budget Law contains multiyear projections by type of expense and by ministry;

- The three-year investment plan (PTI) for 2017-19 prepared by the National Development Planning Directorate (DNDP) provides the three-year sliding investment plan; 
- The Special Budget for Investment (BSI), which is the annual component of the three-year investment plan, is incorporated into the budget. The PTI reflects all project costs as well as annual expenditure for each project for a three-year period;

- All ministries prepare sectoral Medium-Term Expenditure Frameworks (CDMT).

45. Mali's Multiyear capital expenditure programming system is largely consistent. The multiyear budgeting mechanism secures the allocation of resources for public investments. The programming tools (DPEBP and PTI) are consistent with the annual budget. The mechanism to carry funds forward is used as follows: systematically for externally financed expenditure; or subject to a government's decision for domestically financed expenditure. Progress made in multiyear budget management will be further consolidated by the gradual implementation of commitment control through commitment authorizations and payment allocations, scheduled to kick off in 2018.

\section{Budget comprehensiveness}

46. The Budget reflects general government's capital expenditure. It includes capital expenditure by the central government, decentralized administration, and transfers to local governments and public institutions. Capital expenditure (that contributes to gross fixed capital formation) is incorporated into Title $V$ of the budget and is subsequently distributed into two subcategories: (i) equipment (particularly furnishings, buildings, and renovations); and (ii) investments (all domestically and externally financed projects considered mature and structuring, reported in the special capital budget). However, the current budget documentation does not include any specific information on transactions in connection with PPPs, as this mechanism is in the process of being established.

\footnotetext{
${ }^{5}$ The DPEBP et the PTI are being published on the Malian Ministry of Finance website.
} 
Table 6. Distribution of Capital Expenditure, 2015-2017

\begin{tabular}{|l|r|r|r|}
\hline \multicolumn{1}{|c|}{ In billions of CFAF } & \multicolumn{1}{c|}{$\mathbf{2 0 1 5}$} & \multicolumn{1}{c|}{$\mathbf{2 0 1 6}$} & \multicolumn{1}{c|}{$\mathbf{2 0 1 7}$} \\
\hline Capital expenditure & $\mathbf{6 4 9 . 5}$ & $\mathbf{8 0 3 . 3}$ & $\mathbf{8 6 4 . 8}$ \\
\hline Domestic financing & $\mathbf{3 3 9 . 1}$ & $\mathbf{5 2 4 . 7}$ & $\mathbf{5 6 1 . 9}$ \\
\hline Equipment and investment & 189.2 & 289.3 & 274.3 \\
\hline Domestic special capital budget & 149.9 & 235.4 & 287.6 \\
\hline External financing & $\mathbf{2 7 1 . 2}$ & $\mathbf{2 6 0 . 2}$ & $\mathbf{2 8 5 . 1}$ \\
\hline Budget support & $\mathbf{3 9 . 3}$ & $\mathbf{1 8 . 4}$ & $\mathbf{1 7 . 7}$ \\
\hline
\end{tabular}

Source: Boost database/Economic Reform Program for Development.

47. The budget reflects approximately half of the public sector externally financed investments. The budget reflects approved externally financed capital expenditure (i.e. agreed by financing agreements, and proceeded through domestic procedures). Less mature projects that are included in donors' financing projections, and those executed outside of national procedures, are not included in the budget documentation. Local government investments are tracked outside the state budget, in the national fund to support local governments (FNACT). Most of the funds contributing to the FNACT are provided by donors, the rest comprises state endowments and subsidies. For a better overview of public sector investments, a Medium-Term Resource Framework, CRMT 2016-2018, was prepared by the Secretariat for Aid Harmonization (SHA). The amount, in terms of financial volume, of extrabudgetary project aid reported in the CRMT reflects approximately 40-50 percent of the total project support for the period 2015-2018 (See Figure 19).

Figure 19. Capital Expenditure, Off Budget External Financing (in billions of CFAF)

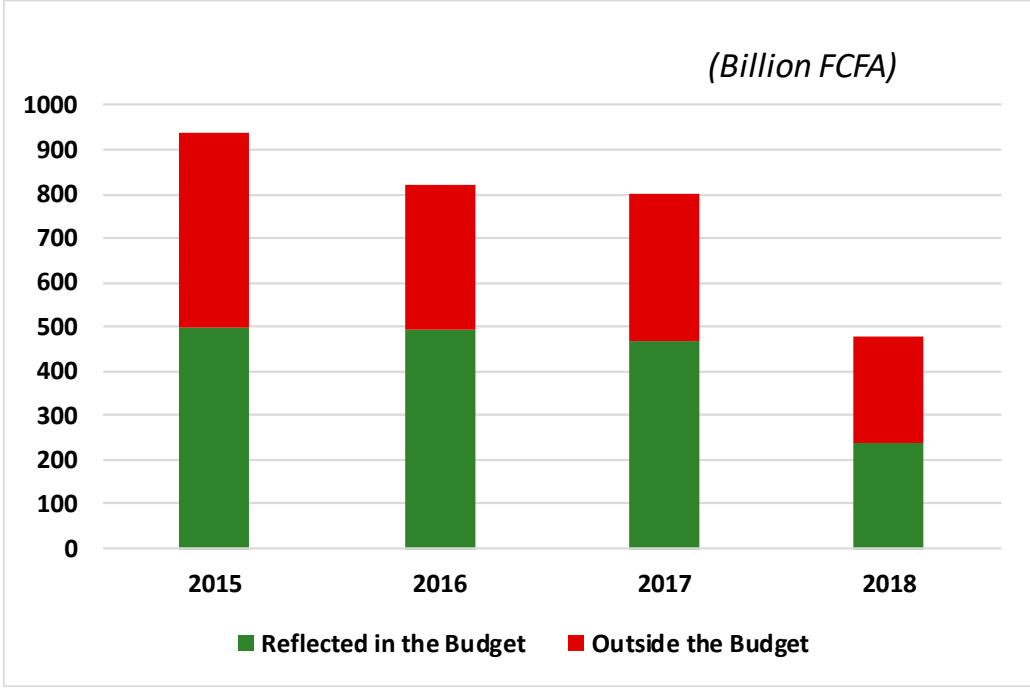

Source: CRMT 2016 - 2018. 


\section{Budget unity}

48. Capital expenditure is presented in a single document using a classification compliant with international standards. Budget expenditure (capital and current) is presented in the Budget Law using economic, administrative, and functional nomenclature according to the IMF Government Finance Statistics Manual 2001 and directives of the WAEMU. The annexes to the Budget include an indicative presentation of the budget by program. The economic classification used places capital expenditure, expenditure in connection with the current operation of projects, and capital expenditure of the ministries and institutions under Title V. When the data are reprocessed, the nomenclature makes it possible to identify structuring projects and capital expenditure by ministries and institutions.

\section{Some capital expenses can be recorded under other items than capital} expenditure. Appropriations for cross-department expenditure comprise both capital and current expenditure and are not broken down by ministry or institution. Certain capital expenditure items are recorded in topical trust funds outside the budget. These shortcomings undermine sectoral programming of investment and capital expenditure.

\section{Recurring expenditure included in the budget are not connected with the relevant}

projects. While the project programming manual requires the sector ministries to estimate recurring costs for their main projects, in practice, this is not carried out. Estimates of recurring charges, and identification of mechanisms for financing them are conducted only for projects with costs in excess of CFAF 1 billion. Road maintenance costs are included in the three-year investment plan. They are presented as investment projects, compliant with the existing budget classification. With the exception of the program for refurbishment of public buildings (included in the special capital budget), there are generally no budget lines specifically related to recurring expenditure (upkeep, maintenance, and renovation) for infrastructures, as they are built.

\section{Project assessment}

51. Sound project assessments allow effective selection of projects, and foster project's implementation through a more effective preparation and a more controlled execution. It offers a unified, uniform, and prioritized view of investment projects. It ensures that projects fit into policy priorities. It defines the conceptual options underpinning the policy decisions. It assesses the socioeconomic impacts, and the fiscal risks and mitigation measures in connection with the project. Implementing one standardized assessment framework helps streamline and optimize the selection process. 
52. In Mali, there is not yet a standard methodology for ex ante assessments. Since 2014 the DNPD, on MoF's behalf, has been managing a fund to finance project studies and preparation for the design of sectoral bankable projects. However, these funds are insufficient to enable the systematic, complete assessment of all projects. There is no standard methodology for ex ante assessment and cost-benefit analyses are not systematically conducted on major projects. Some factors of preliminary feasibility, feasibility, and economic and social returns on investment are included in the selection criteria, although they are not systematically implemented. The donors assess and approve investments financed with external resources using their own systems.

53. Since 2014, a technical committee conducts the investment projects selection. The committee, chaired by the representative of the minister responsible for planning, is comprised of representatives from the DNPD, the DGB, the Directorate General of Public Procurement (DGMP), the National Financial Supervision Directorate (DNCF), the National Treasury and Public Accounting Directorate (DNTCP), and strategic planning units (CPS). Its mission is to study, assess, and select public investment projects to be included in the three-year investment plan and the special capital budget. The committee holds two ordinary sessions per year. The template for projects submitted to the committee by the sector ministries includes the following information: (i) identification of the project, duration, and operating sector (ii) the region in which the project will be executed and the central and/or local financing level; (iii) the provisional schedule for the project, covering the entire management cycle (preparation, execution, and post-project activities); (iv) the project performance framework (general objectives, specific objectives, and activities); ( $v$ ) the framework for forecasting and monitoring of physical and financial outcomes; and (vi) identification and projection of domestic and external financing.

54. In practice, ministries are experiencing problems in conducting ex ante assessments of projects. Due to a lack of technical capacity of project designers, the information submitted to the DNPD is often incomplete. It yields limited socioeconomic impact studies, and poor assessments of the relevance, sustainability, and economic and financial returns of investment. In contrast, donor financed projects, prepared with technical and financial support, are generally better, and often include cost-benefit analysis.

55. Project assessments do not systematically include risk assessments. The analysis of major problems and difficulties is generally provided in the project monitoring and assessment sheet for projects that are in progress. However, there is no ex ante analysis of risks potentially affecting the attainment of project objectives. The authorities consider this point to be a major weakness for which capacity development is required. 


\section{Project selection}

56. While it is robust and well organized, the project selection process lacks transparency. The Mali manual for programming and monitoring and assessment procedures for public investments was validated through a cross-department exercise. It is now being updated. It is used as a reference tool in the selection of sector ministries' projects. It clarifies the roles and responsibilities (at the national and regional levels) and the procedures to be observed at each stage of the public investment management cycle (identification, preparation/formulation, ex ante assessment, implementation/follow-up and evaluation, and ex post assessment). Unfortunately, this manual and the selection criteria and processes that it prescribes are not published at the IMF's website.

57. The criteria for the selection of projects to be included in the three-year investment plan and special capital budget are not published. The examination of projects submitted to the technical selection committee is based on the following unpublished criteria: 1. preliminary criteria: existence of a feasibility study and proper formulation of the project; 2. basic criteria: alignment with the priority operating areas of the strategic framework for economic recovery and development, value added rate, impact on debt service, rate of financing with external resources, impacts on poverty reduction, and number of jobs created; 3. additional criteria: environmental effects, rehabilitation effects for social projects, and integration and disparity reduction effects (multi-regionalism); and 4. budget criteria: availability of financing, level of priority of projects with national counterparts, and assessment and coverage of recurring costs. A weighting system is used within the DNPD to support the selection process.

58. The reform of the selection processes has not yielded all expected outcomes. The new criteria apply only to new projects. No criteria have been established for projects in progress or in the completion stages. As a result of insufficient time and/or technical capacities, and despite the orders from the DNPD and Selection Committee, the sector ministries have yet to internalize the new process and rarely undertake a preselection round before submitting project proposals to the DNPD.

59. There is a need to reassess old projects included in the special capital budget (BSI). The DNPD's implements a voluntarist policy aimed at dropping projects with low value-added or excessively lengthy terms. Nevertheless, the BSI (Figure 20) still includes a number of smallbudget, long lasting projects, some of which should have been terminated, that are ineffectively consuming funds allocated for investments. Only 27 projects (equivalent to 7 percent of the total number of projects) represent 50 percent of the BSI, while 195 projects (equivalent to 50 percent of the total number of projects) have been appropriated with CFAF 500 million or less. Twentyfive percent of these 195 small projects have more than 10-year maturities, and 87 projects are in the near or past completion phases. 
60. Last, there are no assessments on projects' readiness or feasibility. The selection criteria do not include any verification as to whether the projects are ready for execution (such as public procurement schedules, detailed terms of reference, technical specifications, and availability of properties). Absent this technical review, not ready or not feasible projects can be included in the budget, with the risks of substantial delays in the execution of capital expenditure, and adverse impact on the quality of the projects' outputs.

Figure 20. Composition of the Special Capital Budget with Domestic Financing, 2017

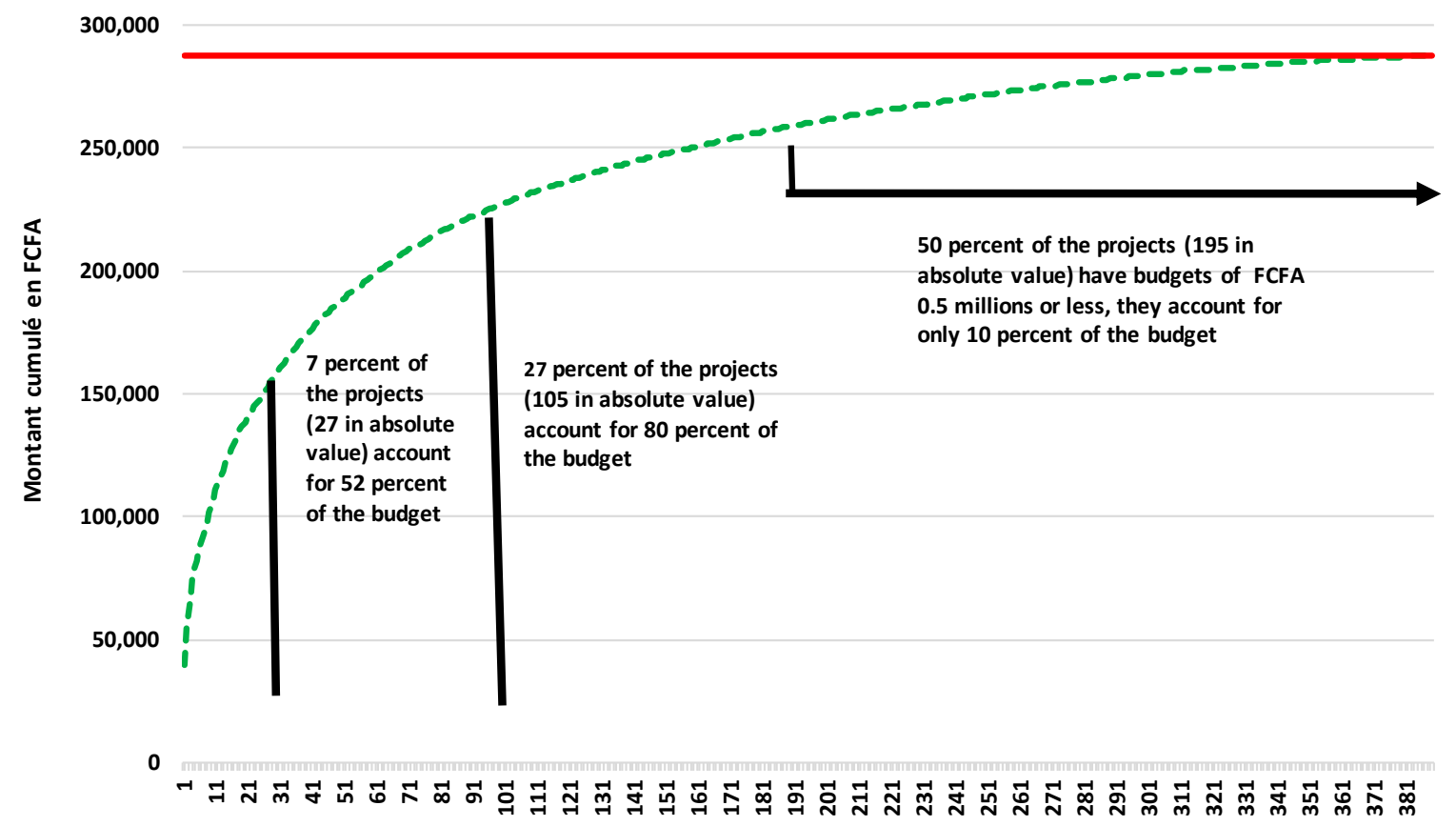

Number of Projects

Source: DGB/Special capital budget.

Pillar II. Key Departures from Best Practices

\begin{tabular}{|c|c|c|}
\hline Institution & Departures & Importance \\
\hline 8 & Program nomenclature still not used & Moderate \\
\hline 8 & Program of economic reform for development in progress, incomplete & Moderate \\
\hline 9 & No standard methodology for preparing assessments & Moderate \\
\hline 9 & Cost-benefit analysis not systematic & High \\
\hline 10 & $\begin{array}{l}\text { Absence of technical review on the quality of studies and whether they can be } \\
\text { executed }\end{array}$ & High \\
\hline
\end{tabular}




\section{Pillar III. Implementing}

61. Public investment must deliver productive, sustainable assets. Economically profitable execution, in a timely manner, of public investment projects requires overall financing, effective management, and transparent follow-up. The third pillar of the PIMA aims to ensure that productive, sustainable assets are delivered. It determines whether all players: (i) have an investment protection mechanism; (ii) ensure that the funds are available; (iii) ensure transparency in project execution; (iv) manage implementation of projects; and (v) monitor public assets.

62. The quality of the institutional framework for investment execution is fairly high, albeit with some weaknesses in asset accounting. Management of project execution is generally effective, and execution of the capital expenditure budget is generally satisfactory. The administration must now implement a more effective accounting and monitoring system. The reforms designed to implement accrual-basis accounting in line with the WAEMU directives will help offset these weaknesses.

Table 7. Summary Assessment, Pillar III

\begin{tabular}{|c|c|c|c|c|}
\hline \multicolumn{2}{|r|}{ Stage/Institution } & Institutional strength & Effectiveness & $\begin{array}{l}\text { Priority } \\
\text { of the } \\
\text { reforms }\end{array}$ \\
\hline 11 & $\begin{array}{l}\text { Protection of } \\
\text { investments }\end{array}$ & $\begin{array}{l}\text { High. Investments are protected under the } \\
\text { institutional framework and the budget } \\
\text { documentation incorporates total project } \\
\text { costs. }\end{array}$ & $\begin{array}{l}\text { Moderate. While effectiveness will } \\
\text { only be perceptible with the full } \\
\text { implementation of information } \\
\text { systems, recent practices permit this } \\
\text { protection. }\end{array}$ & * \\
\hline 12 & $\begin{array}{l}\text { Availability of } \\
\text { financing }\end{array}$ & $\begin{array}{l}\text { Moderate. The regulatory framework } \\
\text { provides for different programming and } \\
\text { management tools but allows the option of } \\
\text { external financing with commercial banks. }\end{array}$ & $\begin{array}{l}\text { Moderate. Although funds are } \\
\text { disbursed in a timely manner, this } \\
\text { availability is undermined by the } \\
\text { absence of commitment plans and } \\
\text { external financing outside of the } \\
\text { treasury single account. }\end{array}$ & ** \\
\hline 13 & $\begin{array}{l}\text { Transparency in } \\
\text { execution }\end{array}$ & $\begin{array}{l}\text { High. The institutional framework provides } \\
\text { for open, transparent public procurement, } \\
\text { physical and financial monitoring of projects, } \\
\text { as well as ex post external audits. }\end{array}$ & $\begin{array}{l}\text { Moderate. In fact, the absence of } \\
\text { traceability in procedures and } \\
\text { coordination between the players } \\
\text { can adversely affect transparency. }\end{array}$ & * \\
\hline 14 & $\begin{array}{l}\text { Management of } \\
\text { implementation }\end{array}$ & $\begin{array}{l}\text { Moderate. While rules apply to project } \\
\text { management and assessment, such rules do } \\
\text { not reflect improvements made to projects } \\
\text { during the process of execution. }\end{array}$ & $\begin{array}{l}\text { Moderate. Effective management is } \\
\text { complicated by weaknesses in the } \\
\text { information system and assessments } \\
\text { are still insufficiently focused on the } \\
\text { expected results. }\end{array}$ & ** \\
\hline 15 & Asset accounting & $\begin{array}{l}\text { Low. The institutional framework for stock } \\
\text { and accrual basis accounting requires more } \\
\text { detailed, operational regulation. }\end{array}$ & $\begin{array}{l}\text { Low. The inventory of public assets } \\
\text { is conducted on a partial basis, the } \\
\text { information is not included on the } \\
\text { balance sheets, and there is no } \\
\text { amortization/depreciation. }\end{array}$ & $* * *$ \\
\hline
\end{tabular}




\section{Protection of investments}

63. Investments are protected under the institutional framework and the budget documentation clearly incorporates total project costs. The Law on Budget Laws (LLF) prescribes budgeting of public investment funds under commitment authorizations at the beginning of the project and under payment allocations adjusted and budgeted on an annual basis. Information on the total cost of the projects is presented in the budget documentation submitted to Parliament. Credit transfers from capital to current expenditure items are exceptional and subject to authorization by decree of the Council of Ministers. Last, unused funds may be carried forward on an unlimited basis, provided that the resources are still available to finance them.

64. Recent practices permit protection of investments; yet the system's effectiveness will only be perceptible with the full implementation of the information systems. In 2017, project financing was allocated on an annual and three-year basis. Moreover, two important mechanisms were implemented: one is protecting investment funds from in-year reallocation, and the other allows to carry-forward investment funds left over at the end of the fiscal year (although the mission was not given the opportunity to review the statements of transfers and carry-forward). When upgraded and compliant with the new legal framework, the information systems will help enforce the rules and mechanisms designed to secure funds for multiyear investment projects.

\section{Upgrading the information systems is a structural change towards an effective} protection of investments. As part of ongoing reforms, Mali is upgrading its budget and accounting applications. A recent technical assistance mission ${ }^{6}$ took stock of budget execution applications, i.e. the "program of economic reform for development" (PRED) and the "integrated government accounting application" (AICE). The mission's recommendations specifically aimed to strengthen medium term protection of investments. Further, projects' data on financial, accounting, and budget execution shall be processed through an improved version of the DNPD's "integrated public investment management system" (SIGIP).

${ }^{6}$ See "Adapter les systèmes informatiques à la gestion des dépenses en budget de programme," [Adapting information systems to management of expenditure with the program budget approach], FAD, Louis d'Humières and Nicolas Botton, April 2017. 


\section{Availability of financing}

66. The framework permits depositing external financing in commercial banks. Per regulations, procurement plans (PPM) are mandatory. Moreover, commitment plans and cash plans are prescribed in application of the decree establishing the general regulation on public accounting (RGCP) deriving from the transposition of the WAEMU directive. The decree's didactic guide sets rules applicable, form, content, and methodology for preparing and revising the commitment and cash plans. Compliant with RGCP all public funds, including external financing, should be deposited into a single treasury account (CUT) at the Central Bank of West African States (BCEAO). According to the RGCP banking arrangements are placed under the purview of the minister of finance who must approve the opening of accounts with the following derogatory options: (i) as for donors' financing set up through financing agreements funds should be deposited on Mali's national territory at the BCEAO or at a commercial banks; (ii) as for other financing to be used on Mali's national territory funds can be deposited at commercial banks; and (iii) as for financing used abroad funds can be deposited at foreign financial institutions agreed by the minister of finance.

\section{The absence of external financing and commitment plans outside of the CUT} impedes availability of funds. The authorities implement public procurement plans through the integrated public procurement management system (SIGMAP). However, as a result of technical problems, not all users have access to this system. Hence comprehensiveness and quality of the information, both as entered and updated, is not guaranteed. In addition, commitment plans have not been implemented yet. Therefore, programming and management tools, upstream the cash plan, are not coherent, which undermines the reliability of the cash plan. Efforts made to extend the CUT coverage to external financing should be pursued.

\section{Nevertheless, Mali has not accumulated payment arrears on capital expenditure} over the past two fiscal years. In 2015 and 2016, funds in connection with projects were disbursed in a timely manner, i.e., 90 days after they were recorded in the accounting system (the mission had the opportunity to analyze the state's 2015 general balance sheet). The definition of payment arrears is provided in Box 2 below.

\section{Box 2. Definition of Payment Arrears on Capital Expenditure}

The decree establishing the table of government financial operations (TOFE) provides that " residual balances payable will be comprised of any validated payments that have not been settled. They include funds in transit and payment arrears. Funds in transit are comprised of all payments validated and not settled that are less than three months old. Payment arrears are comprised of all payments validated and not settled that are more than three months old. ».

This definition, which strictly reflects the definition under the WAEMU community directive as defined in connection with the program concluded with the IMF, involves using the event underlying the validation of the expenditure rather than its recording in the accounting system.

Source: Decree 2014-0350/PR-M of May 22, 2014. 
69. Inconsistency between programming and management plans is a major weakness and a substantial departure from good practices. The authorities should improve resource management to avoid delays or disruption in project execution as a result of the unavailability of funds. The best way to do so is to update, reconcile and share data tracked through sectoral public procurement plans (PPMS), consolidated public procurement plans (PPMCs), sectoral commitment plans (PES) and consolidated commitment plans (PECs), and cash plans. Setting all plans consistently is particularly important to avoid accumulation of payment arrears, as Mali has experienced in the recent past.

\section{Transparency in execution}

\section{The institutional framework provides for openness and transparency in public} procurement operations, physical and financial monitoring of projects, and ex post external audits. The framework for public procurement ${ }^{7}$ promotes openness and transparency in the public procurement process. It sets such principles for public procurement as the free access to public tenders, public disclosure, and transparency. In addition, Mali's regulatory texts ${ }^{8}$ and donor procedures applicable to externally financed projects provide that major investment projects must be subject to physical and financial monitoring during the implementation phase as well as to an ex post audit. The regulatory authority for public procurement and public service delegation ${ }^{9}$ (ARMDSP), the Accounting Section of the Supreme Court, ${ }^{10}$ as well as the Auditor General ${ }^{11}$ are legally competent to conduct these external audits.

\section{The lack of traceability and poor coordination between the players can adversely} affect transparency. The public has full, reliable, timely access to information. There is, however, room to improve the traceability of public procurement procedures (see infra). The following weaknesses can adversely affect transparency: the lack of coordination between the many players involved (Box 3); and poorly interconnected information systems.

\footnotetext{
7 See Decree 2015-0604 of September 25, 2015 Establishing the Code on Public Procurement and Public Service Delegation in reference above.

${ }^{8}$ See Manual of Procedures for Programming and Monitoring-Assessment of Public Investment in Mali developed by the DNPD in May 2005, currently in the process of being amended, as well as the monitoring and assessment manuals developed in connection with different sectoral policies.

${ }^{9}$ See Article 2 of Law 2008-023 of July 23, 2008 on the ARMDSP.

10 See Article 116 of Law 2016-046 of September 23, 2016 in Respect of the Organic Law Establishing the Organization, Operating Rules of the Supreme Court, and the Procedure Followed before the Supreme Court.

${ }^{11}$ See Article 2 of Law 2012-009 of February 8, 2012 Superseding Law 03-030 of August 25, 2003 Instituting the Auditor General.
} 


\section{The authorities must encourage better information sharing and strengthen}

coordination. Externally-financed projects are often carried out by units under loose oversight by their relevant sector ministry-hence the need for the MoF to systematically coordinate with the sector ministries for an improved integration of projects into the sectoral policies. Better coordination between the many control bodies can improve the effectiveness of the audits. Outcomes from these audits should be published, and incriminated managers should be held accountable and sanctioned when necessary.

\section{Box 3. Players Involved in Execution Processes}

The finance and materials directorates (DFM), strategic planning units (CPS), and project management units in the sector ministries, for physical and financial monitoring;

The DNCF, for preliminary financial supervision on commitments and when the services are provided;

The Directorate General of Public Procurement and Public Service Delegation and the Regulatory Authority for Public Procurement and Public Service Delegation in the area of public procurement supervision;

The DGB for budget supervision;

The DNTCP for accounting and financial monitoring;

The external auditors assigned by the government or donors, for externally financed projects, in connection with ex post external audits;

The DNPD for tools in connection with monitoring and assessment, and the consolidation of information;

The various ministerial inspection bodies;

The Accounting Section of the Supreme Court and the Auditor General of Mali;

And last, Parliament.

Source: Mission. 
Management of project implementation

73. While rules apply to project management and assessment, such rules do not apply to changes made to projects during the process of execution. Per donors' procedures and Mali legal framework ${ }^{12}$ ex post reviews are required; and a project management team, led by a project coordinator, should be systematically appointed for project implementation. However, this institutional framework does not mention any specific rules for the adjustment or redevelopment of projects, except for amendments to the public procurement contracts.

74. Management is adversely affected by weaknesses in the information systems. The sector ministries with which the mission met, systematically designate a senior manager for major investment projects. However, the mission was unable to assess the implementation plans prepared prior to the approval of the budget. Moreover, management of project implementation is complicated by the insufficient information system, as the Mali authorities still do not have a system that they can use to monitor large projects, from planning to the end result, and to consolidate the information. The DNPD is planning to roll out an upgrade of its SIGIP integrated public investment management system in ministries' planning units (CPS).

75. The assessments are still insufficiently focused on the expected results. While rules and procedures apply to amendments to procurement contracts, it is not required yet to conduct reviews or reassessments of the justification, costs, or expected results of amended projects. Last, there are few reviews or assessments of completed projects, and those conducted focus more on outputs than projects' outcomes.

Monitoring of public assets

76. The regulations on asset management are insufficiently detailed and operational. A more detailed, operational regulatory framework will be necessary to succeed in the gradual implementation until $2019^{13}$ of accrual accounting, a reform that will allow a more effective monitoring and management of public assets. The Directorate General of Government Asset Management (DGABE), has drafted a md is updating relevant regulations. ${ }^{14}$ Even so, this framework must be operationalized, in partnership with the unit responsible for setting accounting standards, to define best possible methods for asset valuation and amortization. Where accrual and net worth accounting is concerned, the DNTCP is continuing its efforts to draft a compendium of government accounting standards, including standards on assets, which should subsequently be documented through technical specifications for full operational implementation.

\footnotetext{
${ }^{12}$ See the texts in reference above in connection with the Accounting Section of the Supreme Court and the Auditor General of Mali.

${ }^{13}$ In accordance with Article 103 of the RGCP in reference above.

${ }^{14}$ See Decree 10-681/PR-M of December 30, 2010 on Regulations Governing Stock Accounting.
} 


\section{The inventory of public assets is partial, no information is incorporated into the} balance sheets, and there is no amortization/depreciation. In fact, different units maintain nonfinancial assets lists which comprehensiveness and timeliness are dubious. Accordingly, the ministries are taking stock of assets, using the DGABE tools, for central and decentralized units. This stock taking does not involve a valuation of assets surveyed, in the absence of any defined valuation methods (see above). In addition, the central government balance sheets do not include information on nonfinancial assets: the accounting assessment mechanism designed to reclassify budget operations under fixed assets has not been implemented yet. Last, the depreciation of tangible assets, although provided in the government chart of accounts, ${ }^{15}$ has yet to be recorded in the operating accounts. Although implementation of asset monitoring is planned for 2019, the preparatory works should now be carried out so that this extensive effort can be completed.

Pillar III. Key Departures from Best Practices

\begin{tabular}{|c|c|c|}
\hline Institution & Gaps & Importance \\
\hline 12 & $\begin{array}{l}\text { No commitment plan, insufficient correlation between financial } \\
\text { programming instruments. }\end{array}$ & Moderate \\
\hline 14 & $\begin{array}{l}\text { No information system accessible to all participants to permit } \\
\text { physical and financial monitoring of projects. }\end{array}$ & Moderate \\
\hline 14 & $\begin{array}{l}\text { There is still further scope for development in the approach of } \\
\text { assessing expected project results. }\end{array}$ & High \\
\hline 15 & Implementation of accrual accounting has not been completed. & High \\
\hline
\end{tabular}

\section{Cross-Cutting Issues and Capacities}

78. This section of the assessment addresses cross-cutting issues in public investment management. A good management system requires implementation of robust, effective components applicable to all phases and institutions involved in the management cycle. The factors assessed involve capacities (e.g. human and information technology), regulatory frameworks (e.g. those applicable to management in general and to public procurement in particular), and infrastructure recurring costs (i.e. maintenance and upkeep).

\section{The human and technical capacities of Mali's government are satisfactory and are} improving. The accounting and budget systems have developed to reflect changes in practices and in the regulatory framework. It would be advantageous for these systems to be slightly better integrated and for projects to be subject to ongoing supervision, from selection to completion. Staff training to accompany these changes is also recommended.

\footnotetext{
${ }^{15}$ See Title V of Decree 2014-0774/PR-M of October 14, 2014 on the Government Chart of Accounts.
} 
80. The quality of the institutional framework for public procurement is high and its effectiveness is improving. The public procurement code (provisions of the law and regulatory texts) have developed effectively to reflect requirements, and the authorities report progress in the implementation of this framework, although there is scope for further progress in terms of transparency and contracting periods.

81. Confirmation and budgeting of infrastructure maintenance costs is a weakness that should be corrected. Maintenance costs are generally not effectively assessed or reflected in the budget. This recurring weakness may, aside from budget, environmental, and geopolitical difficulties, explain the constant attrition in Mali's stock of infrastructures as reported above (see Section 1, Paragraph 11, Figure 7).

Table 8. Summary Assessment of Cross-Cutting Issues and Capacities

\begin{tabular}{|c|c|c|c|c|}
\hline \multicolumn{2}{|c|}{ Étape/Institution } & \multirow{2}{*}{$\begin{array}{l}\text { Cadre institutionnel } \\
\text { Moderate. The regulatory framework, } \\
\text { which is being updated, incorporates } \\
\text { public investment requirements. There is } \\
\text { a need for staff capacity and information } \\
\text { technology strengthening. }\end{array}$} & \multirow{2}{*}{$\begin{array}{l}\text { Effectivité } \\
\text { Moderate. Lack of tools and } \\
\text { exchanges of information deny a } \\
\text { comprehensive monitoring of } \\
\text { projects from planning to execution. } \\
\text { Training plans should improve. } \\
\end{array}$} & \multirow{2}{*}{$\begin{array}{l}\text { Priorité des } \\
\text { réformes } \\
\qquad * *\end{array}$} \\
\hline 16 & $\begin{array}{l}\text { Cross-cutting } \\
\text { issues }\end{array}$ & & & \\
\hline 17 & $\begin{array}{c}\text { Public } \\
\text { procurement }\end{array}$ & $\begin{array}{l}\text { High. According to the legal framework, } \\
\text { the procurement process should be } \\
\text { open and transparent, contracts be } \\
\text { subject to physical and financial } \\
\text { monitoring in coordination with the } \\
\text { contracting authorities, and be audited. }\end{array}$ & $\begin{array}{l}\text { Moderate. Public procurement } \\
\text { arrangements could be more } \\
\text { transparent, open, and effective; } \\
\text { timing delays may adversely affect } \\
\text { transparency and efficacy. }\end{array}$ & $* *$ \\
\hline 18 & Maintenance & $\begin{array}{l}\text { Moderate. Certain ministries have rules } \\
\text { and methodologies to assess major } \\
\text { projects' recurring costs. These } \\
\text { methodologies, however, are not } \\
\text { harmonized or consolidated. }\end{array}$ & $\begin{array}{l}\text { Low. Maintenance costs, when } \\
\text { assessed, are not systematically or } \\
\text { comprehensively included in the } \\
\text { budget. }\end{array}$ & $* * *$ \\
\hline
\end{tabular}

Integration of the information system

82. An information system enables effective management of public investments when it is adapted, accessible to all, and used by competent, trained personnel. The information technology tools make it possible to monitor projects from start to finish, to apply the regulatory framework and produce documents, data, and analyses needed by the relevant services. Last, staff must be trained to optimize these tools.

83. The Mali information systems for public investments are not unified and process partial information. The tools and media used to collect information to be reported (in hardcopy form) are submitted to the ministries so that projects can be selected for inclusion in the three-year investment plan. The information is next entered into the DNPD's SIGIP. However, this information is not comprehensive and is not transmitted to the applications used by other units (such as the DGB, DNTCP, and DGMP). The system does not provide the possibility of an overview of a given project from the ex-ante assessment to maintenance costs monitoring. Computer applications are not yet capable of automated exchange for that purpose, as shown in the Figure below. 
Figure 21. Information Systems Involved in Public Investment Management Are Not Integrated

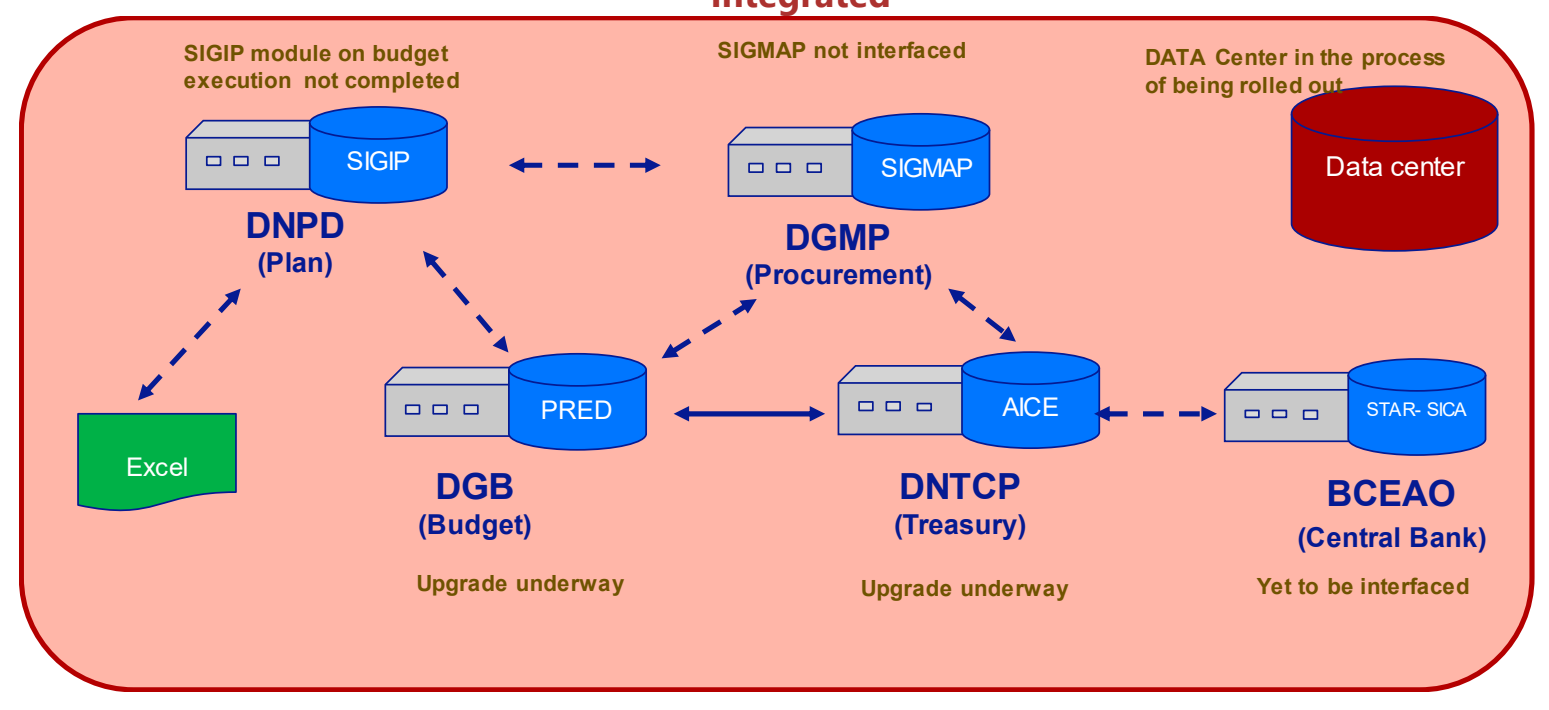

Source: IMF Paper, Adapter les systèmes informatiques à la gestion des dépenses en budget de programme [Adapting information systems to expenditure management under program budgets], Louis d'Humières and Nicolas Botton, April 2017.

\section{The system is being modernized in the context of an information technology} master plan (SDI). The works involve development of the application interfaces missing in connection with the modernization of the existing applications, and involving a number of directorates general. However, to build a unified management process and view of investment projects, there is a need for a central cross-steering mechanism, separate from the steering mechanisms applicable to modernization of the existing systems. This approach would improve coordination between different programming and budgeting tools for public investment. For that purpose, the DNPD must not only complete implementation of the monitoring and assessment module for its application; it should also ensure that developments in other applications are monitored.

\section{Legislative and regulatory framework}

\section{While the regulatory framework is consistent and has been updated, its} implementation is still limited in certain phases of public investment management. In particular, the framework includes the following Law and subregulations:

- 2013-028 of July 11, 2013 Transposing Directive 06/2009/CM/UEMOA

- 2013-031 of July 23, 2013 Transposing Directive 1/2009/CM/UEMOA Establishing the Code of Transparency in Financial Management,

- Decree 2014-0694/P-RM of September 12, 2014 on Budget Nomenclature, 
- Decision 007/MPP-SG of March 27, 2014 Establishing the Selection Committee for Public Investment Programs,

- Decree 08-485/P-RM of August 11, 2008 Establishing the Public Procurement Code in the Republic of Mali,

- $\quad$ and a Manual of Public Procurement Contracting Procedures for Local Governments established under Interministerial Decree 10-0203/MEF/MATCL-SG.

However, some aspects of this framework have only been partially implemented (see comments under Pillars 1, 2, and 3 above).

86. Upcoming provisions under the 2018 Budget Law would lead to durable improvements. Many reforms are planned for 2018: multiyear management through commitment authorizations and payment allocations, new rules for fund reallocations, and the program budget. Effective implementation of these reforms should improve capital expenditure management; and transparency should be enhanced with the issuance of annual performance report and projects, and of multiyear projections.

\section{Human resource capacities}

\section{The capacities of the teams responsible for management of public investments} are moderate and can be undermined by excessive turnover. While the ministries' training plans provide for strengthening the competence of the strategic planning units, training progress is undermined by excessive staff turnover, while requirements for supplementary training are becoming increasingly demanding. In practice, while the DNPD provides training on management of public investments (programming/budgeting as well as monitoring and assessment) for newly hired staff, those in the strategic planning units do not always receive this initial training. Hence, there is a shortage of expertise in certain areas, including: risk analysis in the ex-ante assessment of projects; recurring cost assessments; and PPPs.

\section{A number of reforms in progress require additional efforts for training and} providing support in connection with the changes involved. Multiyear management, the program budget, accrual accounting for assets, and management of recurring costs, in particular, are examples of innovations requiring support in connection with the relevant organizational units and capacity development for the staff involved. No cross-cutting training plans have been established to date. 


\section{Procurement contracting}

This institution particularly affects Pillar III in connection with the execution of investment projects, and relates specifically to Institution 13 on transparency in budget execution.

\section{The legal framework promotes open, transparent procedures and rigorous}

monitoring of contracts. The new regulatory framework for public procurement contracting promotes openness and transparency in procurement contracting processes. The regulatory framework specifies that public requests for tenders are the default contracting mechanisms. This procedure is supplemented with restricted invitations to tender (in which at least three sets of bidding documents are required, as in the case of intellectual creative services) and with direct contracting (or by mutual agreement). The concepts of free access to public procurement and its transparency are given the same consideration as the principles of economy, efficacy, and equitable treatment. The regulatory framework also specifies that procurement contracts executed may be subject to physical and financial control during the implementation phase and to a posteriori supervision by the body responsible for regulating public procurement contracting and public service delegation. Last, the regulatory framework establishes efficacy, transparency, and traceability as principles in contracting procedures.

Figure 22. Procurement Trends

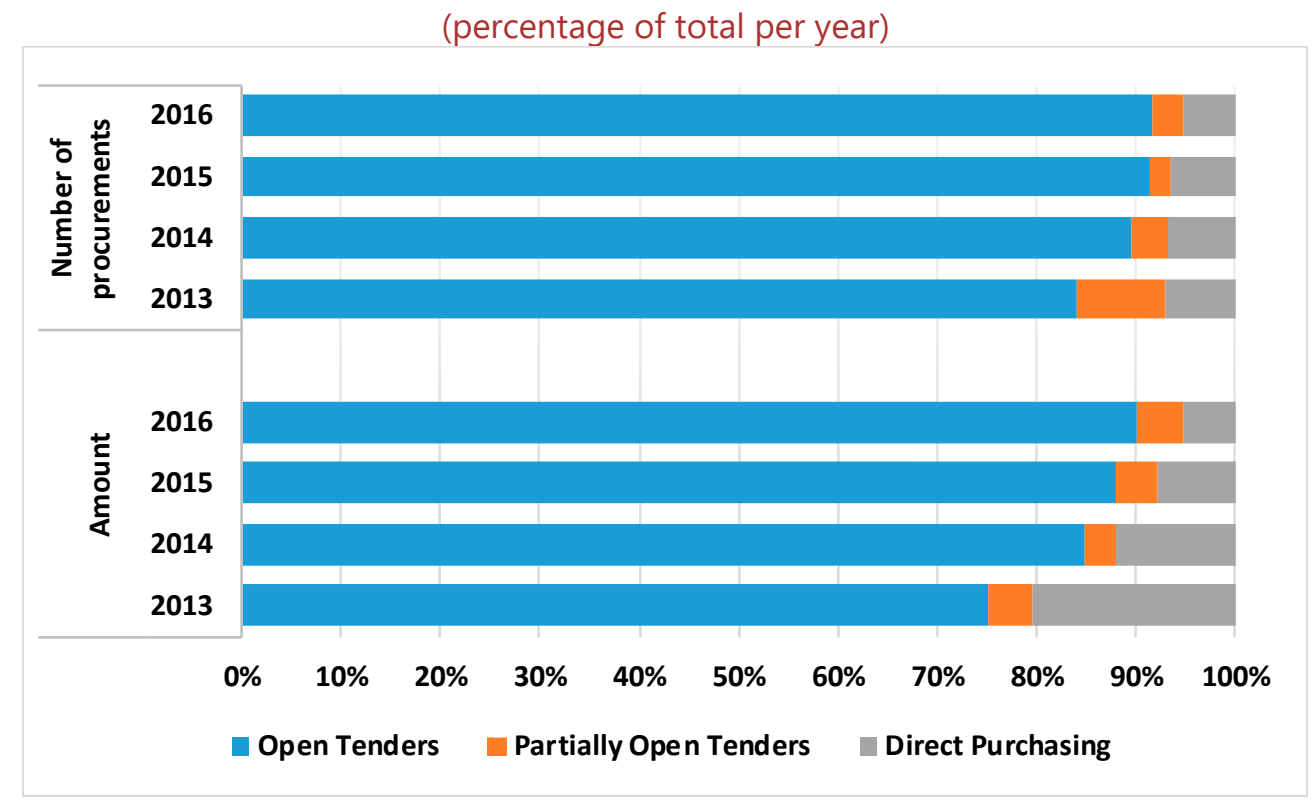

Source: DGMP, 2017. 


\section{In practice, there is scope for improvement in the efficacy and traceability of the} procedures involved. Figure 22 above shows a clear improvement: between 2013 and 2016, more than 90 percent of the contracts were executed through public requests for tenders, and this proportion is increasing. Comprehensive public access to information is provided through the publication of requests for tenders in newspapers and at the websites of the DGMP and the ARMDS. The DGMP also ensures that procedures are traceable through the database, that has been operational since January 1, 2017, and that provides an interface between the DGMP and the contracting authorities. However, this system is still quite recent, and access to the database, regularity, periodicity of production, and sharing of reports produced based on this information stand to be improved. Similarly, there is also scope for improvement in the process of physical and financial supervision undertaken by the DGMP in collaboration with the contracting authorities. Some contracts also fall outside of the DGMP's supervision (more specifically procurement arrangements in connection with delegated developers-MDODs). Last, despite the recent progress that has been made, on average, public contracting delays generally exceed the regulatory periods ${ }^{16}$ (Table 9 below), particularly those specified for the signing of the contracts.

\footnotetext{
${ }^{16}$ In practice, the contracting periods can clearly exceed the average periods listed in the above table, particularly the contract signing stages, which can require more than three months in certain cases.
} 
Table 9. Public Procurement Contracting Periods

\begin{tabular}{|c|c|c|c|}
\hline (in number of days) & $\begin{array}{l}\text { Regulatory } \\
\text { periods }\end{array}$ & $\begin{array}{l}\text { Average period } \\
\text { in } 2015\end{array}$ & $\begin{array}{l}\text { Average period } \\
\text { in } 2016\end{array}$ \\
\hline Document processing period (DAO) & 12 & 13 & 19 \\
\hline $\begin{array}{l}\text { Average period for publication of requests for } \\
\text { tenders }\end{array}$ & 37 & 30 & 30 \\
\hline $\begin{array}{l}\text { Average period between the opening of bids } \\
\text { and forwarding of the assessment reports to } \\
\text { the supervisory body }\end{array}$ & 10 & 9 & 21 \\
\hline Processing of assessment reports & 11 & 5 & 7 \\
\hline Processing of draft contracts & 10 & & \\
\hline $\begin{array}{l}\text { Average time between signing by the } \\
\text { successful bidder and approval of the contract }\end{array}$ & 6 & 30 & 25 \\
\hline Average general periods & 86 & 87 & 102 \\
\hline
\end{tabular}

Source: DGMP, 2017.

\section{Recurring maintenance and upkeep costs}

This institution has a particular incidence on Pillar II in respect of investment project programming and relates specifically to Institution 8 on budget unity.

\section{The calculation of recurring costs is rudimentary and even nonexistent in some} sectors. Investment projects' recurring maintenance and upkeep costs must be calculated and identified for each year in the project document, particularly for projects exceeding CFAF 1 billion. There are methodologies based on standard costs to determine maintenance costs (education, health, road maintenance fund, etc.). However, not all sectors have such methodologies and those that exist are not harmonized or consolidated.

\section{In practice, funds allocated to recurring costs are insufficient to ensure the}

sustainability of infrastructures. Maintenance costs, when assessed at the sector level and included in the project specifications must be integrated into the budgets of the sector ministries or local authorities, resources permitting. The corresponding funds, however, are not specifically related to investment projects, which introduces a disconnect between the planning and budgeting of recurring maintenance costs. Moreover, as a result of the insufficient quality of maintenance expenditure, it is not always clear that the investments will be properly maintained. Figure 23 below shows the upward trend in maintenance funds introduced in recent years into the budget laws, although without specifically leading to improved preservation of infrastructures. Last, amortization/depreciation expenditure is not identified in the government's financial statements. 
Figure 23. Trends in Maintenance Costs Under the State Budget

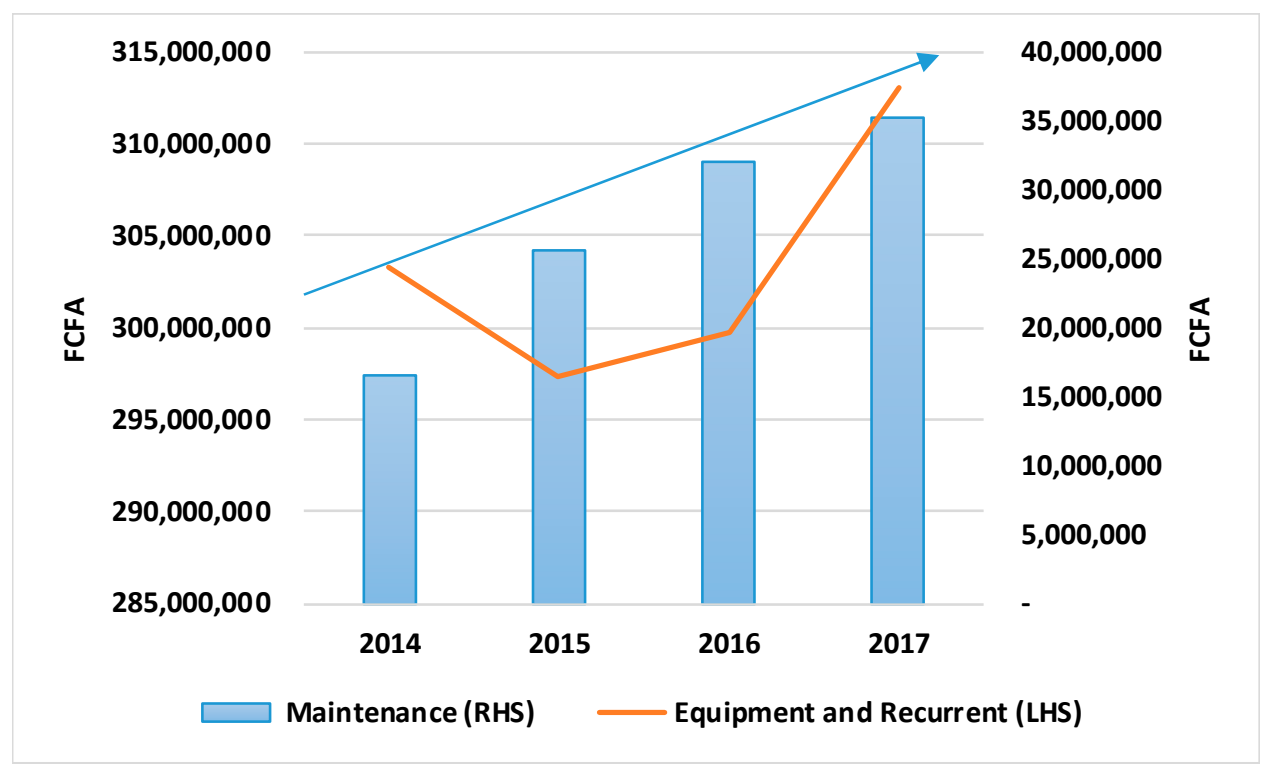

Source: Ministère des Finances, 2017.

Pillar III. Key Departures from Best Practices

\begin{tabular}{|c|c|c|}
\hline Institution & Departures & Importance \\
\hline 16 & $\begin{array}{l}\text { No integrated system accessible to stakeholders so that projects can be } \\
\text { managed throughout their cycle. }\end{array}$ & High \\
\hline 16 & $\begin{array}{l}\text { The strategic planning units can lack competence and training, and turnover } \\
\text { levels are high. }\end{array}$ & Moderate \\
\hline 17 & $\begin{array}{l}\text { Some bottlenecks are still present in procurement contracting, despite serious } \\
\text { improvements. }\end{array}$ & Low \\
\hline 18 & $\begin{array}{l}\text { Disparate methodologies and insufficient budget coverage for recurring } \\
\text { costs. }\end{array}$ & High \\
\hline 18 & Maintenance expenditure is insufficient. & High \\
\hline
\end{tabular}




\section{RECOMMENDATIONS AND ACTION PLAN}

\section{The action plan and recommendations below reflect the findings that}

management is robust while, paradoxically, it is also inefficient. In Mali, the management framework is fairly robust when compared with countries in the subregion and other developing countries, although it produces low levels of sustainable fixed capital. The management system does not produce a sustainable stock of fixed capital that reflects the investment efforts that have been made. This poor performance derives from a substantial efficiency gap: only 57 percent of Mali's investment spending materializes in fixed capital, compared to an average 73 percent in other countries throughout the world.

\section{The proposed activities are designed to optimize the management framework by} establishing a results-based administrative culture. Consistent with the above-mentioned paradox (a fairly robust, albeit inefficient system), the plan is designed to optimize the institutional framework, not to structurally change it. The purpose of this approach is to change the administrative culture and practices to produce more infrastructures, more sustainable and of higher quality. Three approaches are proposed: 1 . to optimize existing resources; 2 . to mobilize resources and devote them to investment; and 3. to improve the sustainability of the stock of infrastructures. A cross-cutting approach (4) aiming to establish a results-based culture of integrity through an enhanced professional standard of management must support the implementation of these three operational approaches.

Figure 24. Structure of the Action Plan

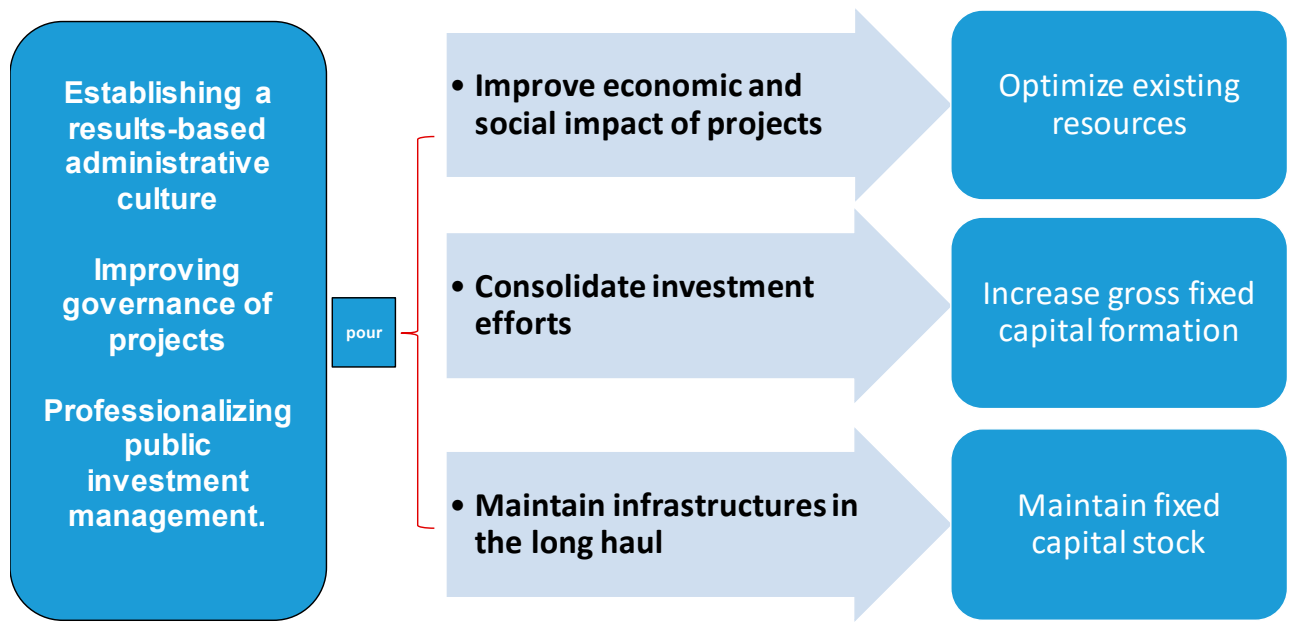




\begin{tabular}{|c|c|c|c|c|c|c|c|c|c|}
\hline Recommendations & Activities & Urgent & 17 & 18 & 19 & $\begin{array}{c}\text { Subsequent } \\
\text { treatment }\end{array}$ & Players & Institutions & $\begin{array}{l}\text { Tech. } \\
\text { assist. }\end{array}$ \\
\hline \multicolumn{10}{|c|}{ CROSS-CUTTING AREA: STRENGTHEN GOVERNANCE FOR PUBLIC INVESTMENT MANAGEMENT } \\
\hline \multirow{3}{*}{$\begin{array}{l}\text { 1. Develop capacities } \\
\text { and tools to } \\
\text { establish a culture of } \\
\text { transparency and } \\
\text { performance }\end{array}$} & $\begin{array}{l}\text { Use the program budget } \\
\text { reform to develop } \\
\text { accountability and } \\
\text { performance of managers } \\
\text { and to adapt the } \\
\text { administrative structures } \\
\text { and practices. Develop } \\
\text { performance contracts for } \\
\text { the project heads and } \\
\text { structures. }\end{array}$ & & & & & & $\begin{array}{l}\text { MEF, Support } \\
\text { Unit for Fiscal } \\
\text { Reform } \\
\text { (CARFIP), all } \\
\text { services }\end{array}$ & All & $x$ \\
\hline & $\begin{array}{l}\text { Develop capacities through } \\
\text { induction and ongoing } \\
\text { training activities, } \\
\text { specifically on risk analysis, } \\
\text { financial analysis, and } \\
\text { monitoring of physical } \\
\text { project execution. }\end{array}$ & & & & & & $\begin{array}{l}\text { DNPD } \\
\text { DGB } \\
\text { CPS }\end{array}$ & All & \\
\hline & $\begin{array}{l}\text { Hold strategic planning unit } \\
\text { meetings at the inter- } \\
\text { ministerial level on a } \\
\text { quarterly basis as a forum to } \\
\text { exchange information on } \\
\text { good practices and case } \\
\text { studies. }\end{array}$ & & & & & & DNPD & All & \\
\hline
\end{tabular}




\begin{tabular}{|c|c|c|c|c|c|c|c|c|c|}
\hline Recommendations & Activities & Urgent & 17 & 18 & 19 & $\begin{array}{c}\text { Subsequent } \\
\text { treatment }\end{array}$ & Players & Institutions & $\begin{array}{l}\text { Tech. } \\
\text { assist. }\end{array}$ \\
\hline & $\begin{array}{l}\text { Share a common view of } \\
\text { each investment project } \\
\text { through the adaptation of } \\
\text { the information systems and } \\
\text { interfaces in all directorates } \\
\text { of the MEF (and particularly } \\
\text { the DNPD). }\end{array}$ & & & & & & $\begin{array}{l}\text { DNPD } \\
\text { DGB } \\
\text { DGMP } \\
\text { DNTCP } \\
\text { IT Support } \\
\text { Unit for the } \\
\text { Tax and } \\
\text { Financial } \\
\text { Departments } \\
\text { (CAISFF) }\end{array}$ & All & \\
\hline $\begin{array}{l}\text { 2. Involve civil } \\
\text { society and the local } \\
\text { governments to } \\
\text { improve the efficacy } \\
\text { of maintenance and } \\
\text { receiving of new } \\
\text { infrastructures }\end{array}$ & $\begin{array}{l}\text { Hold an annual regional } \\
\text { meeting for CROCSAD, } \\
\text { CLOCSAD, and CCOSAD } \\
\text { coordinated by the } \\
\text { governors and the DNPD on } \\
\text { the topic of infrastructure } \\
\text { maintenance and financial } \\
\text { execution of capital budgets } \\
\text { to identify local } \\
\text { requirements and take them } \\
\text { into account. }\end{array}$ & & & & & & $\begin{array}{l}\text { CROCSAD } \\
\text { CLOCSAD } \\
\text { CCOSAD }\end{array}$ & $3,8,18$ & \\
\hline
\end{tabular}




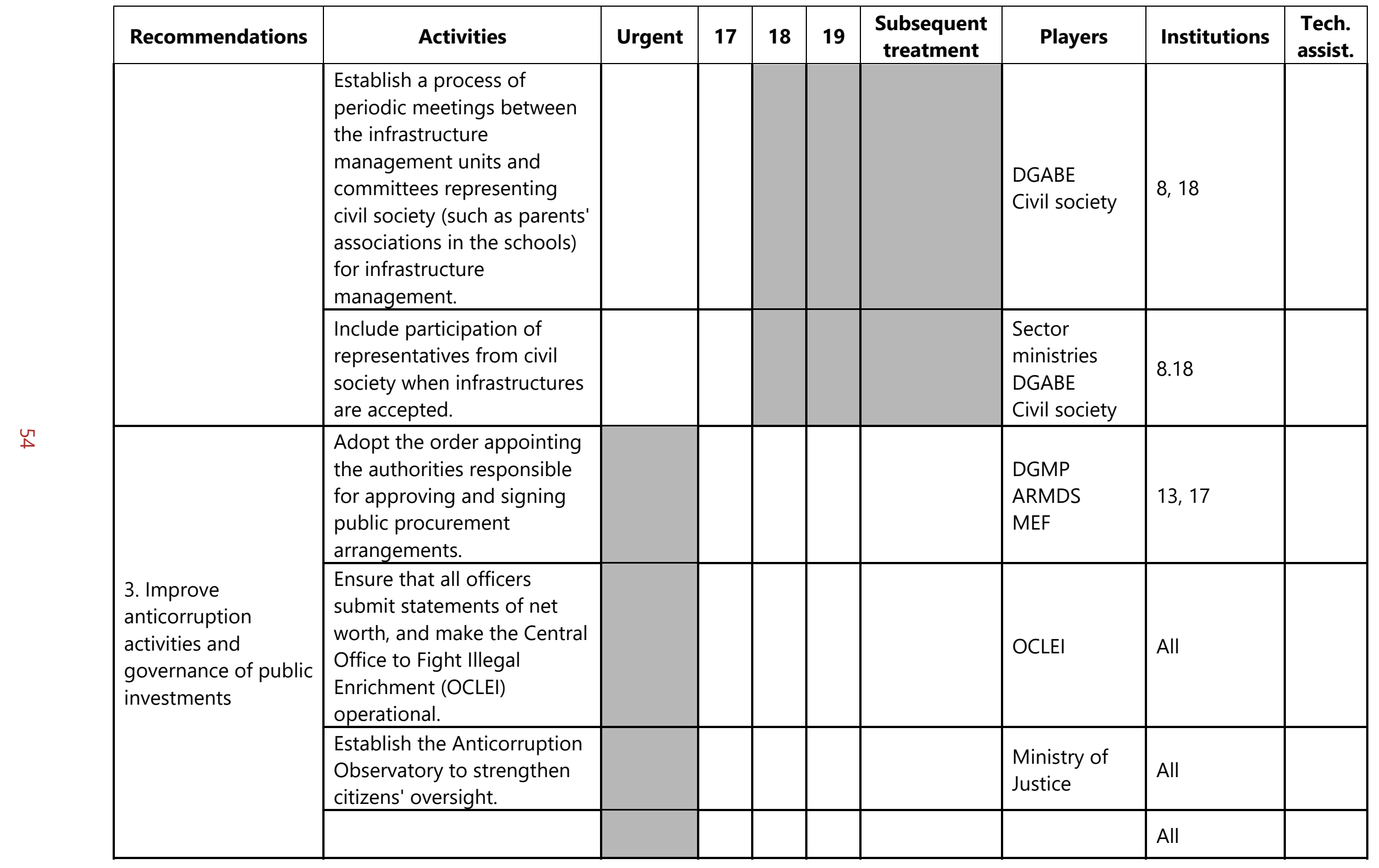




\begin{tabular}{|c|c|c|c|c|c|c|c|c|c|}
\hline \multirow[t]{2}{*}{ Recommendations } & Activities & Urgent & 17 & 18 & 19 & $\begin{array}{c}\text { Subsequent } \\
\text { treatment }\end{array}$ & Players & Institutions & $\begin{array}{l}\text { Tech. } \\
\text { assist. }\end{array}$ \\
\hline & $\begin{array}{l}\text { Publish judgments of the } \\
\text { commercial courts and } \\
\text { other courts on governance } \\
\text { topics. }\end{array}$ & & & & & & $\begin{array}{l}\text { Ministry of } \\
\text { Justice }\end{array}$ & & \\
\hline \multicolumn{10}{|c|}{ AREA 1. IMPROVE THE SOCIOECONOMIC IMPACT OF INVESTMENT } \\
\hline \multirow{4}{*}{$\begin{array}{l}\text { 4. Strengthen the } \\
\text { process of selecting } \\
\text { investment projects }\end{array}$} & $\begin{array}{l}\text { Update the programming } \\
\text { and monitoring and } \\
\text { assessment manuals for } \\
\text { projects, project } \\
\text { specifications, and the } \\
\text { definition of the reference } \\
\text { framework for projects (this } \\
\text { activity has been partially } \\
\text { completed: a draft reference } \\
\text { framework is available). }\end{array}$ & & & & & & $\begin{array}{l}\text { DNPD } \\
\text { DGB } \\
\text { CPS }\end{array}$ & 10 & \\
\hline & $\begin{array}{l}\text { Add selection criteria and } \\
\text { apply them to projects } \\
\text { being executed and those in } \\
\text { the final stages. }\end{array}$ & & & & & & $\begin{array}{l}\text { DNPD } \\
\text { Selection } \\
\text { Committee }\end{array}$ & 10 & \\
\hline & $\begin{array}{l}\text { Systematically conduct an } \\
\text { initial arbitrage in the sector } \\
\text { ministries and put low-cost } \\
\text { projects together before the } \\
\text { project proposals are } \\
\text { forwarded to the DNPD. }\end{array}$ & & & & & & $\begin{array}{l}\text { Ministries } \\
\text { CPS } \\
\text { DNPD }\end{array}$ & 10 & \\
\hline & $\begin{array}{l}\text { Publish the criteria adopted } \\
\text { for the selection of projects } \\
\text { at the MEF website. }\end{array}$ & & & & & & $\begin{array}{l}\text { DNPD } \\
\text { MEF }\end{array}$ & 10 & \\
\hline
\end{tabular}




\begin{tabular}{|c|c|c|c|c|c|c|c|c|c|}
\hline Recommendations & Activities & Urgent & 17 & 18 & 19 & $\begin{array}{c}\text { Subsequent } \\
\text { treatment }\end{array}$ & Players & Institutions & $\begin{array}{l}\text { Tech. } \\
\text { assist. }\end{array}$ \\
\hline \multirow{3}{*}{$\begin{array}{l}\text { 5. Clean up the } \\
\text { three-year } \\
\text { investment plan }\end{array}$} & $\begin{array}{l}\text { Review the three-year } \\
\text { investment plan project } \\
\text { database to reflect the } \\
\text { duration of the projects } \\
\text { involved and the amount } \\
\text { allocated to each project (to } \\
\text { avoid spreading funds too } \\
\text { thinly). }\end{array}$ & & & & & & $\begin{array}{l}\text { DNPD } \\
\text { DGB } \\
\text { Selection } \\
\text { Committee }\end{array}$ & 10 & \\
\hline & $\begin{array}{l}\text { Conduct a general review of } \\
\text { old projects to identify } \\
\text { those to be discontinued } \\
\text { and budget those to be } \\
\text { maintained in the portfolio } \\
\text { as a priority. Combine } \\
\text { projects with small residual } \\
\text { amounts to optimize their } \\
\text { operating costs. Terminate } \\
\text { inactive projects that do not } \\
\text { generate fixed capital. }\end{array}$ & & & & & & DGB & 8 & \\
\hline & $\begin{array}{l}\text { Adopt and apply } \\
\text { standardized rules and } \\
\text { procedures for the } \\
\text { adjustment of projects to } \\
\text { reflect the justification, } \\
\text { costs, and expected results } \\
\text { of a given project. } \\
\end{array}$ & & & & & & DNPD & 14 & $x$ \\
\hline & & & & & & & DNPD & 9 & \\
\hline
\end{tabular}




\begin{tabular}{|c|c|c|c|c|c|c|c|c|c|}
\hline Recommendations & Activities & Urgent & 17 & 18 & 19 & $\begin{array}{c}\text { Subsequent } \\
\text { treatment }\end{array}$ & Players & Institutions & $\begin{array}{l}\text { Tech. } \\
\text { assist. }\end{array}$ \\
\hline \multirow{5}{*}{$\begin{array}{l}\text { 6. Strengthen ex } \\
\text { ante/ex post } \\
\text { assessments }\end{array}$} & $\begin{array}{l}\text { Organize training/coaching } \\
\text { sessions before issuing } \\
\text { project specifications } \\
\text { (consistently with the annual } \\
\text { budget schedule). }\end{array}$ & & & & & & $\begin{array}{l}\text { Selection } \\
\text { Committee }\end{array}$ & & \\
\hline & $\begin{array}{l}\text { Replenish funds for project } \\
\text { studies and preparation to } \\
\text { expand their scope of use, } \\
\text { particularly for systematic ex } \\
\text { ante/ex post assessments of } \\
\text { major projects, and clearly } \\
\text { specify the conditions for } \\
\text { eligibility. }\end{array}$ & & & & & & $\begin{array}{l}\text { DNPD } \\
\text { Selection } \\
\text { Committee }\end{array}$ & 9 and 14 & \\
\hline & $\begin{array}{l}\text { Define the thresholds } \\
\text { making it possible to }\end{array}$ & & & & & & DNPD & & \\
\hline & $\begin{array}{l}\text { identify investments of } \\
\text { major importance and } \\
\text { adopt a standard cost- } \\
\text { benefit analysis framework } \\
\text { for these projects, including } \\
\text { a risk analysis. }\end{array}$ & & & & & & $\begin{array}{l}\text { CPS } \\
\text { Ministries }\end{array}$ & 9 & \\
\hline & $\begin{array}{l}\text { Generalize ex post reviews } \\
\text { and assessments of } \\
\text { completed projects focusing } \\
\text { on their efficiency and } \\
\text { socioeconomic impact, and } \\
\text { publish the assessment } \\
\text { reports. }\end{array}$ & & & & & & $\begin{array}{l}\text { External } \\
\text { auditors } \\
\text { Accounting } \\
\text { section } \\
\text { Auditor } \\
\text { General }\end{array}$ & 14 & \\
\hline
\end{tabular}




\begin{tabular}{|c|c|c|c|c|c|c|c|c|c|}
\hline Recommendations & Activities & Urgent & 17 & 18 & 19 & $\begin{array}{c}\text { Subsequent } \\
\text { treatment }\end{array}$ & Players & Institutions & $\begin{array}{l}\text { Tech. } \\
\text { assist. }\end{array}$ \\
\hline & $\begin{array}{l}\text { Submit an annual annex as } \\
\text { provided under the LOLF } \\
\text { describing central and local } \\
\text { investment operations in } \\
\text { connection with the budget } \\
\text { discussions. This } \\
\text { presentation will highlight } \\
\text { the performance of } \\
\text { investment from the } \\
\text { previous year, its } \\
\text { socioeconomic impact, and } \\
\text { the status of major projects. }\end{array}$ & & & & & & $\begin{array}{l}\text { DNPD, DGB, } \\
\text { DNTCP, } \\
\text { ANICT }\end{array}$ & 13,14 & \\
\hline \multicolumn{10}{|c|}{ AREA 2: CONSOLIDATE THE INVESTMENT EFFORT } \\
\hline \multirow[t]{2}{*}{$\begin{array}{l}\text { 7. Improve the } \\
\text { composition of the } \\
\text { capital budget }\end{array}$} & $\begin{array}{l}\text { Reduce the share of } \\
\text { operating expenditure and } \\
\text { wages in projects by } \\
\text { introducing an efficiency } \\
\text { criterion targeting a ratio of } \\
85 \text { percent capital } \\
\text { expenditure per project. } \\
\text { Incorporate projects having } \\
\text { a substantial impact on fixed } \\
\text { capital formation into the } \\
\text { budget. }\end{array}$ & & & & & & $\begin{array}{l}\text { DGB } \\
\text { DNPD } \\
\text { CPS }\end{array}$ & 8 & \\
\hline & $\begin{array}{l}\text { Align the functional } \\
\text { classification with } \\
\text { international standards to } \\
\text { facilitate socioeconomic } \\
\text { impact analyses. }\end{array}$ & & & & & & $\begin{array}{l}\text { DGB } \\
\text { DNPD } \\
\text { CPS }\end{array}$ & 8 & \\
\hline
\end{tabular}




\begin{tabular}{|c|c|c|c|c|c|c|c|c|c|}
\hline Recommendations & Activities & Urgent & 17 & 18 & 19 & $\begin{array}{c}\text { Subsequent } \\
\text { treatment }\end{array}$ & Players & Institutions & $\begin{array}{l}\text { Tech. } \\
\text { assist. }\end{array}$ \\
\hline \multirow{2}{*}{$\begin{array}{l}\text { 8. Increase the share } \\
\text { of investments } \\
\text { financed with } \\
\text { domestic resources }\end{array}$} & $\begin{array}{l}\text { Increase mobilization of } \\
\text { revenue through more } \\
\text { efficient fiscal controls and } \\
\text { an expanded tax assessment } \\
\text { base. }\end{array}$ & & & & & & $\begin{array}{l}\text { DGI } \\
\text { DGD }\end{array}$ & 1 & \\
\hline & $\begin{array}{l}\text { Increase the resources of } \\
\text { the local governments by } \\
\text { transferring } 30 \text { percent of } \\
\text { the budget revenue to the } \\
\text { local governments. }\end{array}$ & & & & & & $\begin{array}{l}\text { DGB } \\
\text { ANICT }\end{array}$ & 3 & \\
\hline \multirow{2}{*}{$\begin{array}{l}\text { 9. Gain control of } \\
\text { risks in connection } \\
\text { with management of } \\
\text { public investment by } \\
\text { private players }\end{array}$} & $\begin{array}{l}\text { Publish an implementing } \\
\text { decree for the Law on PPPs } \\
\text { establishing (i) the principle } \\
\text { of a legal ceiling on } \\
\text { commitments or } \\
\text { guarantees; and (ii) } \\
\text { organizing coordination of } \\
\text { financial surveillance. }\end{array}$ & & & & & & $\begin{array}{l}\text { Public-Private } \\
\text { Partnership } \\
\text { Unit } \\
\text { DGB }\end{array}$ & 4 & \\
\hline & $\begin{array}{l}\text { In connection with the } \\
\text { organizational reform of the } \\
\text { DGB, which is in the process } \\
\text { of being implemented, } \\
\text { identify and specialize staff } \\
\text { responsible for financial } \\
\text { surveillance of PPPs and } \\
\text { public enterprises. }\end{array}$ & & & & & & DGB & 4,5 & \\
\hline
\end{tabular}




\begin{tabular}{|c|c|c|c|c|c|c|c|c|c|}
\hline \multirow[t]{4}{*}{ Recommendations } & Activities & Urgent & 17 & 18 & 19 & $\begin{array}{c}\text { Subsequent } \\
\text { treatment }\end{array}$ & Players & Institutions & $\begin{array}{l}\text { Tech. } \\
\text { assist. }\end{array}$ \\
\hline & $\begin{array}{l}\text { Publish an inter-ministerial } \\
\text { order establishing the } \\
\text { procedure for reporting } \\
\text { financial information to the } \\
\text { DGB by the DGABE, the } \\
\text { DGDP, oversight ministries, } \\
\text { and public enterprises. }\end{array}$ & & & & & & $\begin{array}{l}\text { Public-Private } \\
\text { Partnership } \\
\text { Unit } \\
\text { DGB } \\
\text { DGABE } \\
\text { DGDP } \\
\text { Sector } \\
\text { ministries } \\
\text { Public } \\
\text { enterprises } \\
\end{array}$ & 4,5 & \\
\hline & $\begin{array}{l}\text { Develop financial analysis } \\
\text { capacities for PPPs and } \\
\text { financial statements of } \\
\text { public enterprises. }\end{array}$ & & & & & & DGB & 4,6 & $x$ \\
\hline & $\begin{array}{l}\text { Publish as an annex to the } \\
\text { Budget Law a consolidated } \\
\text { report on any liabilities in } \\
\text { connection with PPPs and } \\
\text { the financial performance of } \\
\text { public enterprises. }\end{array}$ & & & & & & DGB & 4,6 & \\
\hline $\begin{array}{l}\text { 10. Ensure that funds } \\
\text { are made available } \\
\text { to projects in a } \\
\text { timely manner }\end{array}$ & $\begin{array}{l}\text { Strengthen the quality and } \\
\text { comprehensiveness of } \\
\text { information provided } \\
\text { upstream in procurement } \\
\text { contracting plans by } \\
\text { extending the coverage and } \\
\text { functionalities of SIGMAP. }\end{array}$ & & & & & & $\begin{array}{l}\text { DGMP-DSP } \\
\text { Sector } \\
\text { ministries } \\
\text { DNCF }\end{array}$ & 12 & \\
\hline
\end{tabular}




\begin{tabular}{|c|c|c|c|c|c|c|c|c|c|}
\hline Recommendations & Activities & Urgent & 17 & 18 & 19 & $\begin{array}{c}\text { Subsequent } \\
\text { treatment }\end{array}$ & Players & Institutions & $\begin{array}{l}\text { Tech. } \\
\text { assist. }\end{array}$ \\
\hline & $\begin{array}{l}\text { Develop commitment plans } \\
\text { for sector and consolidated } \\
\text { expenditure, particularly by } \\
\text { incorporating data from the } \\
\text { procurement contracting } \\
\text { plans. }\end{array}$ & & & & & & $\begin{array}{l}\text { Sector } \\
\text { ministries } \\
\text { DNCF } \\
\text { DGB }\end{array}$ & 12 & $x$ \\
\hline & $\begin{array}{l}\text { Continue the effort to make } \\
\text { the cash flow plan more } \\
\text { reliable by gradually } \\
\text { reducing discrepancies } \\
\text { between revenue } \\
\text { projections and outturn. }\end{array}$ & & & & & & $\begin{array}{l}\text { DNTCP } \\
\text { DGI } \\
\text { DGD } \\
\text { DGABE }\end{array}$ & 12 & $\mathrm{x}$ \\
\hline & $\begin{array}{l}\text { Link the commitment plans } \\
\text { to the cash flow plan, and } \\
\text { on this basis, regulate } \\
\text { commitments upstream. }\end{array}$ & & & & & & $\begin{array}{l}\text { DGMP } \\
\text { DGB } \\
\text { DNTCP }\end{array}$ & 12 & $x$ \\
\hline & $\begin{array}{l}\text { Strengthen the CUT by } \\
\text { gradually incorporating } \\
\text { external financing into the } \\
\text { account. }\end{array}$ & & & & & & $\begin{array}{l}\text { DNTCP } \\
\text { TFP }\end{array}$ & 12 & \\
\hline \multicolumn{10}{|c|}{ AREA 3: MAINTAIN INFRASTRUCTURES IN THE LONG TERM } \\
\hline $\begin{array}{l}\text { 11. Expand } \\
\text { accounting and } \\
\text { financial information } \\
\text { on public assets }\end{array}$ & $\begin{array}{l}\text { Strengthen and implement } \\
\text { the documentation on } \\
\text { monitoring, assessment, and } \\
\text { amortization/depreciation } \\
\text { of non-financial assets. }\end{array}$ & & & & & & $\begin{array}{l}\text { DGABE } \\
\text { DNTCP }\end{array}$ & 15 & $x$ \\
\hline
\end{tabular}




\begin{tabular}{|c|c|c|c|c|c|c|c|c|c|}
\hline Recommendations & Activities & Urgent & 17 & 18 & 19 & $\begin{array}{c}\text { Subsequent } \\
\text { treatment }\end{array}$ & Players & Institutions & $\begin{array}{l}\text { Tech. } \\
\text { assist. }\end{array}$ \\
\hline & $\begin{array}{l}\text { Continue to conduct } \\
\text { inventories and asses them } \\
\text { for the future opening } \\
\text { balance sheet. }\end{array}$ & & & & & & $\begin{array}{l}\text { DGABE } \\
\text { Sector } \\
\text { ministries } \\
\text { DNCF }\end{array}$ & 15 & $x$ \\
\hline & $\begin{array}{l}\text { Strengthen the linkages } \\
\text { between materials } \\
\text { accounting and general } \\
\text { government accounting, } \\
\text { including through their } \\
\text { respective information } \\
\text { systems. }\end{array}$ & & & & & & $\begin{array}{l}\text { DGABE } \\
\text { DNTCP } \\
\text { CAISFF }\end{array}$ & 15 & $x$ \\
\hline \multirow{3}{*}{$\begin{array}{l}\text { 12. Ensure that } \\
\text { maintenance costs } \\
\text { are covered for the } \\
\text { preservation of } \\
\text { infrastructures }\end{array}$} & $\begin{array}{l}\text { Establish a precise definition } \\
\text { of maintenance and upkeep } \\
\text { costs. }\end{array}$ & & & & & & $\begin{array}{l}\text { DNPD } \\
\text { DGB }\end{array}$ & 8,18 & \\
\hline & $\begin{array}{l}\text { Systematically include } \\
\text { estimates of future } \\
\text { operating and maintenance } \\
\text { costs for investment } \\
\text { projects in the project } \\
\text { specifications or } \\
\text { documentation. }\end{array}$ & & & & & & DNPD & 8,18 & \\
\hline & $\begin{array}{l}\text { Establish one or more } \\
\text { sectoral methodological } \\
\text { guides for the calculation of } \\
\text { operating and maintenance } \\
\text { costs with a list of standard } \\
\text { cost/benefit s. }\end{array}$ & & & & & & $\begin{array}{l}\text { DNPD } \\
\text { CPS }\end{array}$ & 8,18 & $x$ \\
\hline
\end{tabular}




\begin{tabular}{|c|c|c|c|c|c|c|c|c|c|}
\hline Recommendations & Activities & Urgent & 17 & 18 & 19 & $\begin{array}{c}\text { Subsequent } \\
\text { treatment }\end{array}$ & Players & Institutions & $\begin{array}{l}\text { Tech. } \\
\text { assist. }\end{array}$ \\
\hline \multirow{3}{*}{$\begin{array}{l}\text { 13. Organize } \\
\text { governance for } \\
\text { maintenance works } \\
\text { to ensure proper } \\
\text { levels of quality in } \\
\text { maintenance and } \\
\text { upkeep expenditure }\end{array}$} & $\begin{array}{l}\text { Identify the focal points in } \\
\text { certain key ministries to plan } \\
\text { and manage maintenance } \\
\text { and upkeep expenditure, } \\
\text { coordinated by the DGABE. }\end{array}$ & & & & & & $\begin{array}{l}\text { DGABE } \\
\text { Sector } \\
\text { ministries }\end{array}$ & 8,18 & $x$ \\
\hline & $\begin{array}{l}\text { Establish a participative } \\
\text { annual and multiyear } \\
\text { sectoral planning process to } \\
\text { prioritize maintenance and } \\
\text { upkeep activities. }\end{array}$ & & & & & & $\begin{array}{l}\text { Sector } \\
\text { ministries } \\
\text { DGABE }\end{array}$ & 8,18 & $x$ \\
\hline & $\begin{array}{l}\text { Establish a periodic } \\
\text { monitoring process for } \\
\text { maintenance and upkeep } \\
\text { expenditure, in collaboration } \\
\text { with the DGABE. }\end{array}$ & & & & & & $\begin{array}{l}\text { Sector } \\
\text { ministries } \\
\text { DGABE }\end{array}$ & 8,18 & \\
\hline
\end{tabular}




\section{Annex I. PIMA Questionnaire}

\begin{tabular}{|c|l|l|}
\hline \multicolumn{4}{|l|}{$\begin{array}{l}\text { Question } \\
\text { Score 1 red = Very little or not at all } \\
\text { Score } 2 \text { yellow = Somewhat } \\
\text { Score } 3 \text { green = To a greater extent }\end{array}$} \\
\hline 1.a. & $\begin{array}{l}\text { a. Is fiscal policy guided by one or more permanent } \\
\text { fiscal principles, or rules? }\end{array}$ & $\begin{array}{l}\text { While fiscal policy is guided by one or more permanent } \\
\text { fiscal rules, such rules have not been applied during the } \\
\text { past three years, and the law does not provide for the } \\
\text { suspension of the rules in exceptional situations. }\end{array}$ \\
\hline 1.b. & $\begin{array}{l}\text { b. Do fiscal principles or rules constrain capital } \\
\text { spending in the near term? }\end{array}$ & $\begin{array}{l}\text { Capital expenditure is part of an objective or limit } \\
\text { applicable to the overall balance or to total expenditure, } \\
\text { but these levels are expressed in structural terms. }\end{array}$ \\
\hline 1.c. & $\begin{array}{l}\text { c. Are there targets or limits for government } \\
\text { liabilities, debt, or net worth? }\end{array}$ & $\begin{array}{l}\text { There is an objective limit for liabilities, debt, or the net } \\
\text { worth of the state. }\end{array}$ \\
\hline
\end{tabular}

2. National and sectoral planning: Are decisions on the allocation of investments based on sector or multisector strategies?

\begin{tabular}{|c|l|l|}
\hline 2.a. & $\begin{array}{l}\text { a. Does the government publish national and } \\
\text { sectoral strategies for public investment? }\end{array}$ & $\begin{array}{l}\text { A national strategy and sector strategies are published } \\
\text { for public investment. }\end{array}$ \\
\hline 2.b. & $\begin{array}{l}\text { b. Are the government's national and sectoral } \\
\text { strategies or plans for public investment costed? }\end{array}$ & $\begin{array}{l}\text { The government's investment strategies contain general } \\
\text { estimates for overall or sector investment plans. }\end{array}$ \\
\hline 2.c. & $\begin{array}{l}\text { c. Do sector strategies include measurable targets } \\
\text { for the outputs outcomes of investment projects? }\end{array}$ & $\begin{array}{l}\text { The sector strategies contain measurable objectives for } \\
\text { the outputs and results of investment projects (such as } \\
\text { reducing congestion in the road system). }\end{array}$ \\
\hline $\begin{array}{l}\text { 3. Coordination between the central authorities and local governments: Does effective coordination exist between the } \\
\text { investment plans of the central government and the local governments? }\end{array}$ & $\begin{array}{l}\text { The local governments can only borrow for purposes of } \\
\text { investing. }\end{array}$ \\
\hline 3.a. & $\begin{array}{l}\text { a. Are there limits on sub-national governments' } \\
\text { borrowing? }\end{array}$
\end{tabular}




\begin{tabular}{|c|c|c|}
\hline 3.b. & $\begin{array}{l}\text { b. Is capital spending by SNGs coordinated with } \\
\text { central government? }\end{array}$ & $\begin{array}{l}\text { Capital expenditure plans of local governments are } \\
\text { consolidated with those of the central government and } \\
\text { there are formal discussions on investment priorities } \\
\text { between the central government and the local } \\
\text { governments. }\end{array}$ \\
\hline 3.c. & $\begin{array}{l}\text { C. Does central government have a transparent, } \\
\text { rule-based system for making capital transfers to } \\
\text { SNGs, and for providing timely information on such } \\
\text { transfers? }\end{array}$ & $\begin{array}{l}\text { The central government uses a transparent system } \\
\text { based on rules to make capital transfers to local } \\
\text { governments, and the planned transfers are reported to } \\
\text { the local governments at least six months before the } \\
\text { beginning of each fiscal year. }\end{array}$ \\
\hline \multicolumn{3}{|c|}{ 4. Public-private partnerships: Is there a transparent framework for the scrutiny, selection, and oversight of PPP projects? } \\
\hline 4.a. & $\begin{array}{l}\text { a. Has the government published a strategy for } \\
\text { PPPs and issued standard criteria for entering into } \\
\text { PPP arrangements? }\end{array}$ & $\begin{array}{l}\text { No strategies or selection criteria for PPPs have been } \\
\text { published. }\end{array}$ \\
\hline 4.b. & $\begin{array}{l}\text { b. Are PPPs subject to value for money review by a } \\
\text { dedicated PPP unit prior to approval? }\end{array}$ & $\begin{array}{l}\text { All or most PPPs are subject to a review of the quality- } \\
\text { price ratio by a unit specifically responsible for PPPs. }\end{array}$ \\
\hline 4.c. & $\begin{array}{l}\text { c. Is the accumulation of explicit and/or contingent } \\
\text { PPP liabilities systematically recorded and } \\
\text { controlled? }\end{array}$ & $\begin{array}{l}\text { Explicit or contingent liabilities for PPPs are not } \\
\text { systematically recorded and there are no overall limits } \\
\text { applicable to the accumulation of such liabilities. }\end{array}$ \\
\hline \multicolumn{3}{|c|}{$\begin{array}{l}\text { 5. Regulation of infrastructure enterprises: Is there a climate to foster the participation of private and public enterprises in } \\
\text { infrastructure construction? }\end{array}$} \\
\hline 5.a. & $\begin{array}{l}\text { a. Does the regulatory framework support } \\
\text { competition in contestable markets for economic } \\
\text { infrastructure (e.g. power, water, telecoms, and } \\
\text { transport)? }\end{array}$ & $\begin{array}{l}\text { There is domestic and international competition on the } \\
\text { major economic infrastructure markets. }\end{array}$ \\
\hline 5.b. & $\begin{array}{l}\text { b. Are there independent regulators who set the } \\
\text { prices of economic infrastructure services based on } \\
\text { objective economic criteria? }\end{array}$ & $\begin{array}{l}\text { Prices for economic infrastructure services are set by } \\
\text { independent regulators which enjoy full institutional, } \\
\text { financial, and management autonomy. }\end{array}$ \\
\hline
\end{tabular}


5.c.

c. Does the government oversee the investment plans of infrastructure SOEs and monitor their financial performance?

The government does not review investment plans of public infrastructure enterprises or their financial performance.

6. Multi-year budgeting: Does the government prepare medium-term projections of capital spending on a full cost basis?

6.a.

a. Is capital spending by ministry forecasted over a multi-year horizon?

\begin{tabular}{|c|l|}
\hline $6 . b$ & $\begin{array}{l}\text { b. Are there multi-year ceilings on capital } \\
\text { expenditure by ministry or program? }\end{array}$ \\
\hline 6.c. & $\begin{array}{l}\text { c. Are projections of the full cost of major capital } \\
\text { projects over their life cycle published? }\end{array}$
\end{tabular}

Capital expenditure projections broken down by

ministry or program are published with a 3 to 5 -year horizon.

There are multiyear ceilings to limit capital expenditure by ministry or program.

Projections of the total cost of each major investment project for its life cycle are included in the budget documentation.

7. Budget comprehensiveness: To what extent is capital spending undertaken through the budget?

\begin{tabular}{|c|l|l|}
\hline 7.a. & $\begin{array}{l}\text { a. Is capital spending mostly undertaken through } \\
\text { the budget? }\end{array}$ & $\begin{array}{l}\text { Little or no capital expenditure is undertaken by } \\
\text { extrabudgetary entities. }\end{array}$ \\
\hline 7.b. & $\begin{array}{l}\text { b. Are externally funded capital projects included in } \\
\text { the budget documentation? }\end{array}$ & $\begin{array}{l}\text { Investment projects financed with external resources } \\
\text { are annexed to the budget documentation. }\end{array}$ \\
\hline 7.c. & $\begin{array}{l}\text { c. Is information on PPP transactions included in } \\
\text { the budget documentation? }\end{array}$ & $\begin{array}{l}\text { No information on transactions in connection with PPPs } \\
\text { is included in the budget documentation. }\end{array}$ \\
\hline
\end{tabular}

8. Budget unity: Is there a unified budget process for capital and current spending?

\begin{tabular}{|c|l|l|}
\hline 8.a. & $\begin{array}{l}\text { a. Are capital and recurrent budgets prepared and } \\
\text { presented together? }\end{array}$ & $\begin{array}{l}\text { The current and capital expenditure budgets are } \\
\text { prepared by the same ministry and presented in the } \\
\text { same budget document using a classification by } \\
\text { program. }\end{array}$ \\
\hline 8.b. & $\begin{array}{l}\text { b. Does the budget include appropriations of the } \\
\text { recurrent costs associated with capital investment } \\
\text { projects? }\end{array}$ & $\begin{array}{l}\text { Information on recurring costs in connection with } \\
\text { investment projects is available, but is not reflected in } \\
\text { the budget documentation. }\end{array}$ \\
\hline 8.c. & $\begin{array}{l}\text { c. Does the budget classification and chart of } \\
\text { accounts distinguish clearly between recurrent and } \\
\text { capital expenditure, in line with international } \\
\text { standards? }\end{array}$ & $\begin{array}{l}\text { The budget classification and chart of accounts include } \\
\text { certain capital expenditure items in the financing, or } \\
\text { certain financing in capital expenditure items. }\end{array}$ \\
\hline
\end{tabular}


9. Project appraisal: Are project proposals subject to systematic project appraisal?

\begin{tabular}{|c|l|l|}
\hline 9.a. & $\begin{array}{l}\text { a. Are capital projects subject to standardized cost- } \\
\text { benefit analysis whose results are published? }\end{array}$ & $\begin{array}{l}\text { Investment projects do not systematically undergo a } \\
\text { cost-benefit analysis. }\end{array}$ \\
\hline 9.b. & $\begin{array}{l}\text { b. Is there a standard methodology and central } \\
\text { support for the appraisal of projects? }\end{array}$ & $\begin{array}{l}\text { There is a standard methodology or central support } \\
\text { structure for project assessment. }\end{array}$ \\
\hline 9.c & c. Are risks taken into account in project appraisal? & $\begin{array}{l}\text { While project assessments contain an assessment of a } \\
\text { broad range of risks, the budgets do not contain any } \\
\text { reserves to cover any cost overruns that may occur. }\end{array}$ \\
\hline
\end{tabular}

10. Project selection: Are there criteria and institutions in place to guide project selection?

\begin{tabular}{|c|l|l|}
\hline 10.a. & $\begin{array}{l}\text { a. Does the government undertake a central review } \\
\text { of major project appraisals before decisions are } \\
\text { taken to include projects in the budget? }\end{array}$ & $\begin{array}{l}\text { Major projects are subject to a technical review (and not } \\
\text { only an administrative review) by a central ministry (the } \\
\text { Ministry of Finance or the Ministry of Planning) before } \\
\text { they are budgeted. }\end{array}$ \\
\hline 10.b. & $\begin{array}{l}\text { b. Does the government publish and adhere to } \\
\text { standard criteria for project selection? }\end{array}$ & $\begin{array}{l}\text { While there are published criteria for the selection of } \\
\text { projects, they are regularly selected without going } \\
\text { through the required selection process. }\end{array}$ \\
\hline 10.c. & $\begin{array}{l}\text { c. Does the government maintain a pipeline of } \\
\text { approved investment projects for including in the } \\
\text { annual budget? }\end{array}$ & $\begin{array}{l}\text { The government has a complete pipeline of investment } \\
\text { projects that have been subject to thorough analysis, } \\
\text { from which projects are selected to be included in the } \\
\text { annual and medium-term budgets. }\end{array}$ \\
\hline
\end{tabular}

11. Protection of investment: Are investment projects protected during budget implementation?

\begin{tabular}{|c|l|l|}
\hline 11.a. & $\begin{array}{l}\text { a. Are total project outlays appropriated by } \\
\text { Parliament at the time of commencement of a } \\
\text { project? }\end{array}$ & $\begin{array}{l}\text { While project financing is allocated on an annual basis, } \\
\text { information on the total cost of projects is available in } \\
\text { the budget documentation. }\end{array}$ \\
\hline 11.b. & $\begin{array}{l}\text { b. Are in-year transfers of appropriations (virement) } \\
\text { from capital to current spending prevented? }\end{array}$ & $\begin{array}{l}\text { Transfers of funds from capital expenditure to current } \\
\text { expenditure are approved by the ministry of finance. }\end{array}$ \\
\hline 11.c. & $\begin{array}{l}\text { c. Can unspent appropriations for capital spending } \\
\text { be carried over to future years? }\end{array}$ & $\begin{array}{l}\text { Capital expenditure funds that have not been spent can } \\
\text { be carried forward subject to certain limits. }\end{array}$ \\
\hline 12. Availability of funding: Is financing for capital spending made available in a timely manner?
\end{tabular}




\begin{tabular}{|c|l|l|}
\hline 12.a. & $\begin{array}{l}\text { a. Are total project outlays appropriated by } \\
\text { Parliament at the time of commencement of a } \\
\text { project? }\end{array}$ & $\begin{array}{l}\text { Capital expenditure commitment plans are not } \\
\text { prepared or are prepared mechanically as a percentage } \\
\text { of the annual budget. }\end{array}$ \\
\hline 12.b. & $\begin{array}{l}\text { b. Are in-year transfers of appropriations (virement) } \\
\text { from capital to current spending prevented? }\end{array}$ & $\begin{array}{l}\text { Funds in connection with project funds are disbursed } \\
\text { with a delay from time to time, leading to certain delays } \\
\text { in project implementation. }\end{array}$ \\
\hline 12.c. & $\begin{array}{l}\text { c. Can unspent appropriations for capital spending } \\
\text { be carried over to future years? }\end{array}$ & $\begin{array}{l}\text { External financing is essentially kept in commercial bank } \\
\text { accounts outside of the state's accounts with the central } \\
\text { bank/CUT. }\end{array}$ \\
\hline
\end{tabular}

13. Transparency of budget execution: Are major investment projects executed transparently and subject to audit?

\begin{tabular}{|c|l|l|}
\hline 13.a. & $\begin{array}{l}\text { a. Is the procurement process for major capital } \\
\text { projects open and transparent? }\end{array}$ & $\begin{array}{l}\text { While many projects are subject to competitive } \\
\text { procedures, the public has limited access to information } \\
\text { on public procurement contracting. }\end{array}$ \\
\hline 13.b. & $\begin{array}{l}\text { b. Are major capital projects subject to monitoring } \\
\text { during project implementation? }\end{array}$ & $\begin{array}{l}\text { For most major investment projects, the annual costs } \\
\text { and physical progress are monitored during the project } \\
\text { execution phase. }\end{array}$ \\
\hline 13.c. & $\begin{array}{l}\text { c. Are ex-post audits of capital projects routinely } \\
\text { undertaken? }\end{array}$ & $\begin{array}{l}\text { Some major investment projects are subject to an ex } \\
\text { post external audit, and this information is made public } \\
\text { by the external auditor. }\end{array}$ \\
\hline 14. Management & 14.a. project implementation: Are capital projects well managed and controlled during the execution stage? \\
\hline 14.b. & $\begin{array}{l}\text { a. Do ministries have effective project management } \\
\text { arrangements in place? }\end{array}$ & $\begin{array}{l}\text { While the ministries systematically appoint a senior } \\
\text { manager for their major investment projects, } \\
\text { implementation plans are not prepared before the } \\
\text { budget is approved. }\end{array}$ \\
\hline & $\begin{array}{l}\text { b. Has the government issued rules, procedures and } \\
\text { guidelines for project adjustments that are applied } \\
\text { systematically across all major projects? }\end{array}$ & $\begin{array}{l}\text { There are standardized rules and procedures for making } \\
\text { adjustments to projects, that are generally applied but } \\
\text { for which no fundamental assessment or review of the } \\
\text { justification, costs, or expected results of the project is } \\
\text { provided. }\end{array}$ \\
\hline
\end{tabular}




\begin{tabular}{|c|c|c|}
\hline 14.c. & $\begin{array}{l}\text { c. Does the government systematically conduct an } \\
\text { ex post review and evaluation of projects that have } \\
\text { completed their construction phase? }\end{array}$ & $\begin{array}{l}\text { Ex post reviews based on project costs, services to be } \\
\text { provided, and results are carried out from time to time. }\end{array}$ \\
\hline \multicolumn{3}{|c|}{$\begin{array}{l}\text { 15. Monitoring of public assets: Is the value of public assets correctly recorded in the accounting system and reported in the } \\
\text { financial statements? }\end{array}$} \\
\hline 15.a. & $\begin{array}{l}\text { a. Are surveys of the stock, value and condition of } \\
\text { public assets regularly conducted? }\end{array}$ & $\begin{array}{l}\text { The administration takes inventory of assets regularly } \\
\text { for certain sectors or subsectors. }\end{array}$ \\
\hline 15.b. & $\begin{array}{l}\text { b. Are non-financial asset values recorded in the } \\
\text { government balance sheets? }\end{array}$ & $\begin{array}{l}\text { The balance sheet does not include nonfinancial assets, } \\
\text { or contains only aggregate information on nonfinancial } \\
\text { assets. }\end{array}$ \\
\hline 15.c. & $\begin{array}{l}\text { c. Is depreciation of fixed assets captured in } \\
\text { government operating statements? }\end{array}$ & $\begin{array}{l}\text { Depreciation of tangible assets is not recorded in the } \\
\text { operating accounts. }\end{array}$ \\
\hline \multicolumn{3}{|c|}{ 16. Cross-cutting issues (new) } \\
\hline 16.a. & $\begin{array}{l}\text { Is there a comprehensive integrated computerized } \\
\text { information system for public investment projects } \\
\text { to support decision making and monitoring? }\end{array}$ & $\begin{array}{l}\text { There is no integrated management system in place for } \\
\text { investment projects. }\end{array}$ \\
\hline 16.b. & $\begin{array}{l}\text { Is there an adequate legal basis for planning, } \\
\text { budgeting, and implementing capital projects? }\end{array}$ & $\begin{array}{l}\text { Some delays, segmentation, or factors of inefficiency } \\
\text { affect at least one of the phases in the public } \\
\text { investment management process, as a result of the } \\
\text { inadequacy of the legal framework. }\end{array}$ \\
\hline 16.c. & $\begin{array}{l}\text { Do staff capacity constraints impede public } \\
\text { investment management (PIM)? }\end{array}$ & $\begin{array}{l}\text { There are human capacity constraints in certain } \\
\text { segments of the investment management procedure. } \\
\text { These constraints can lead to institutional deficiencies } \\
\text { and adversely affect implementation of the } \\
\text { recommendations. }\end{array}$ \\
\hline \multicolumn{3}{|c|}{ 17. Procurement (new) } \\
\hline 17.a. & $\begin{array}{l}\text { Is the procurement process for major capital } \\
\text { projects open and transparent? }\end{array}$ & $\begin{array}{l}\text { The majority of the major projects are subject to } \\
\text { requests for proposals, and the public has timely access } \\
\text { to comprehensive, reliable information on public } \\
\text { procurement contracting activities. }\end{array}$ \\
\hline
\end{tabular}




\begin{tabular}{|c|l|l|}
\hline 17.b. & Is procurement effectively monitored? & $\begin{array}{l}\text { There is a relatively complete database, although it } \\
\text { does not produce standard analytical queries. }\end{array}$ \\
\hline 17.c. & $\begin{array}{l}\text { Are procurement complaints review process } \\
\text { conducted in a fair and timely manner? }\end{array}$ & $\begin{array}{l}\text { Appeals are examined by an independent institution, } \\
\text { and decisions are made in a timely manner. }\end{array}$ \\
\hline 18. Maintenance Funding: Is maintenance receiving adequate funding? & \multicolumn{2}{|l|}{} \\
\hline 18.a. & $\begin{array}{l}\text { Are routine maintenance costs included in the } \\
\text { annual or multi-annual budget? }\end{array}$ & $\begin{array}{l}\text { There is a standard methodology for determining } \\
\text { maintenance costs. }\end{array}$ \\
\hline 18.b. & $\begin{array}{l}\text { Are capital maintenance projects an integral part of } \\
\text { sectoral and national plans? }\end{array}$ & $\begin{array}{l}\text { There is no standard methodology for determining } \\
\text { amortization/depreciation costs for fixed capital, and } \\
\text { such costs are not reflected in the sector or national } \\
\text { plans. }\end{array}$ \\
\hline 18.c. & $\begin{array}{l}\text { Can expenditures relating to maintenance be } \\
\text { identified? }\end{array}$ & $\begin{array}{l}\text { Routine maintenance costs, amortization/depreciation } \\
\text { costs, and replacement costs are identified in the } \\
\text { budget. }\end{array}$ \\
\hline
\end{tabular}

